Article

\title{
A STATCOM with Supercapacitors for Low-Voltage Ride-Through in Fixed-Speed Wind Turbines
}

\author{
Andrés Felipe Obando-Montaño, Camilo Carrillo *, José Cidrás and Eloy Díaz-Dorado \\ Department of Electrical Engineering, University of Vigo, EEI, Campus Universitario. s/n, \\ Vigo 36310, Spain; E-Mails: felipe.obando@uvigo.es (A.F.O.-M.); jcidras@uvigo.es (J.C.); \\ ediaz@uvigo.es (J.C.) \\ * Author to whom correspondence should be addressed; E-Mail: carrillo@uvigo.es; \\ Tel.: +34-986-813912; Fax: +34-986-812173.
}

Received: 26 June 2014; in revised form: 20 August 2014 / Accepted: 3 September 2014 / Published: 10 September 2014

\begin{abstract}
Fixed-speed wind generator (FSWG) technology has an important presence in countries where wind energy started to be developed more than a decade ago. This type of technology cannot be directly adapted to the grid codes, for example those requirements related to the immunity level under voltage dips. That behavior is typically referred as low-voltage ride through (LVRT), and it usually implies certain reactive and active power injection requirements, both during a voltage dip and during the voltage recovery. In this context, a review is presented of the LVRT exigencies present in some of the countries with the most advanced grid codes (Denmark, Germany, Spain and the United Kingdom). In this paper, the capabilities of STATCOM-based devices for fulfilling the LVRT requirements in FSWGs are analyzed. For this purpose, two technologies are considered: a STATCOM with a supercapacitor, which improves its energy storage features; and a STATCOM with a supercapacitor and a DC-DC converter, to achieve higher discharge levels.
\end{abstract}

Keywords: wind energy; fixed-speed wind generator; STATCOM; supercapacitor; low-voltage ride-through

\section{Introduction}

Currently, wind power is the most promising renewable energy source due its increasing penetration in the world's energy mix. For example, in the European Union at the end of 2012, the installed capacity 
reached $100 \mathrm{GW}$, and $11 \%$ of the electricity generated in the European Union was from wind energy $[1,2]$. In this context, system operators (SOs) are becoming stricter with the use of wind energy sources in terms of their behavior compared with conventional energy sources. This restricted use of wind energy sources is implemented through a continuous updating of their grid codes, where the technical conditions demanded for renewable power plants are stricter, or even more exigent, than those for conventional power plants. Regarding these grid codes, typically one of the most demanding requirements is the low-voltage ride-through (LVRT) capability. This requirement refers to the ability of a generating unit or power plant to withstand a voltage dip, whose profile is established by the SO in the grid code. Furthermore, grid codes usually establish the required behavior in terms of the active and reactive power generation during this voltage dip [3-7].

From the point of view of the technology of wind turbine generators (WTGs), most of the WTGs installed during the boom of wind energy were fixed speed wind generators (FSWGs) formed by induction generators [8]. However, in recent years, the most frequently installed WTGs were variable-speed wind turbines formed by doubly-fed induction generators or by synchronous generators with back-to-back converters [9]. Despite this market tendency, FSWGs have an important presence in countries where wind energy started to be developed more than a decade ago (e.g., in 1995, 70\% of the market was dominated by Squirrel Cage Induction Generators, which decreased to $25 \%$ by 2004) $[8,10]$. According to the Spanish Wind Energy Association (Asociación Empresarial Eólica AEE), by 2009, the total installed wind power capacity was $16.740 \mathrm{MW}$, and those wind turbines with induction generators represented 20\% (3380 MW) [11].

In FSWGs, the induction generator is directly connected to the grid, which makes it difficult for this technology to fulfill almost any grid code requirement. For example, FSWGs are usually disconnected when the voltage drop exceeds $10 \%-20 \%$ with respect to the rated voltage [12]. Commonly, FSWGs have mechanically switched capacitors to assist them with the power factor; however, for LVRT fulfillment, reactive power compensators, such as static VAR compensators (SVC) and static synchronous compensators (STATCOM) $[9,13,14]$, must be used.

A STATCOM is a reactive power compensator that exhibits a good dynamic response with a high control bandwidth and the capability of providing higher currents at low voltage levels [12]. It is also desirable to use a STATCOM due to the possibility of working with decoupled control of the DC-link voltage and the reactive current [15]. However, one of the main drawbacks is the low energy density on the DC link capacitor installed in the STATCOM; this limits the reactive and active power capability of the STATCOM $[16,17]$. An improved version of the STATCOM is called the STATCOM + ES (energy storage). This variant includes a storage device, usually batteries, supercapacitors (SCs), etc. The storage device provides more capabilities to the STATCOM, such as power oscillation damping or mitigation of phase-jump-related disturbances [18-24]. Moreover, the STATCOM + ES can be used for reactive compensation when an LVRT system is implemented [25,26].

The main objective of this paper is to propose a robust and reliable solution that provides FSWG LVRT capability, allowing these types of generators to withstand voltage dips and comply with different grid code requirements. The proposed approach to accomplish this purpose is the use of a STATCOM + ES-based on an SC, which enables not only the fulfillment of the reactive power requirements during a voltage dip, but also the active power requirements, i.e., a complete fulfillment of the LVRT conditions can be achieved. The capability of active power generation is implemented by 
means of an SC and a DC-DC converter in the DC link of the STATCOM [23,27]. One of the main features of SCs is their high energy density and large time constants, which makes them very suitable for short-term applications, such as voltage dips, where the disturbances always last less than a second $[21,28]$ (see Appendix 1 for commercially available SCs).

In this study, the grid codes of the following countries are analyzed to establish the LVRT requirements used to define and simulate the compensation system: Denmark, Germany, Spain and the United Kingdom (UK).

The paper is organized as follows. Section 2 summarizes the LVRT requirements in the grid codes. Section 3 presents the system model, including the STATCOM description. Section 4 presents the proposed compensations systems. Section 5 presents the system control with the decoupled control capability. In Section 6, the method implemented for the simulations is presented. In Section 7, the results of all of the simulations are presented, and finally, the conclusions are presented in Section 8 .

\section{LVRT Requirements in the Grid Codes}

One of the most severe types of disturbances in a power network is a voltage dip. According to international standards, voltage dips are characterized by a temporary reduction of the voltage below a threshold that can last from milliseconds up to minutes [29]. Generally, these voltage dips are caused by short circuits in the transmission network. Due to these faults and with the aim of restoring the network to its pre-fault value, the grid codes require that all generation units, including WTGs, must back up the grid. This requirement is called LVRT, and it requires the WTGs to remain connected to the grid, even if, in some cases, the faults reduce the voltage to zero at the point of common coupling (PCC). Furthermore, limits to the active and reactive power consumption during a voltage dip are established in the grid codes [14]. This paper is focused on analyzing the LVRT behavior of FSWGs, because this is typically one of the most demanding requirements from a technologic point of view. The countries whose grid codes have been taken into account are Denmark, Germany, Spain and the United Kingdom.

\subsection{Denmark}

The Danish grid code has two separate requirements for the connection of WTGs to the grid, one for voltages below $100 \mathrm{kV}$ and the other one for voltages above $100 \mathrm{kV}$. In this paper, the LVRT requirements regarding the voltages above $100 \mathrm{kV}$ [4] are considered due to them being more demanding (e.g., active power generation) and also because the profile in both codes is the same. In Figure 1, the voltage profile is shown that the WTGs must withstand without disconnection. This profile is only valid for three-phase short circuits.

This code also establishes that the wind farm shall produce the rated power no later than $10 \mathrm{~s}$ after the voltage recovers the 0.9 p.u. (per-unit system) during the voltage dip. The active power in the PCC shall meet the following condition:

$$
P_{\text {actual }} \geq k p \cdot P_{t=0} \cdot\left(\frac{U_{\text {actual }}}{U_{t=0}}\right)^{2}
$$


where:

- $\quad P_{\text {actual: }}$ the actual active power measured in the PCC;

- $\quad P_{t=0}$ : the power measured in the PCC immediately before the voltage dip;

- $U_{t=0}$ : the voltage in the PCC immediately before the voltage dip;

- $U_{\text {actual: }}$ the actual voltage measured in the PCC;

- $K p=0.4$ : the reduction factor considering any voltage dips at the generator terminals.

During the voltage dip, the wind farm is allowed to consume a reactive current equal to the nominal current at most. The Danish SO also established the use of a simulation model that shall be based on the Thévenin equivalent of the power system. In this equivalent, the grid impedance is characterized by a short-circuit power ten-times higher than the wind turbine's rated power and an impedance ratio of 0.1 [4].

Figure 1. Low-voltage ride-through (LVRT) profile in the Danish grid code.

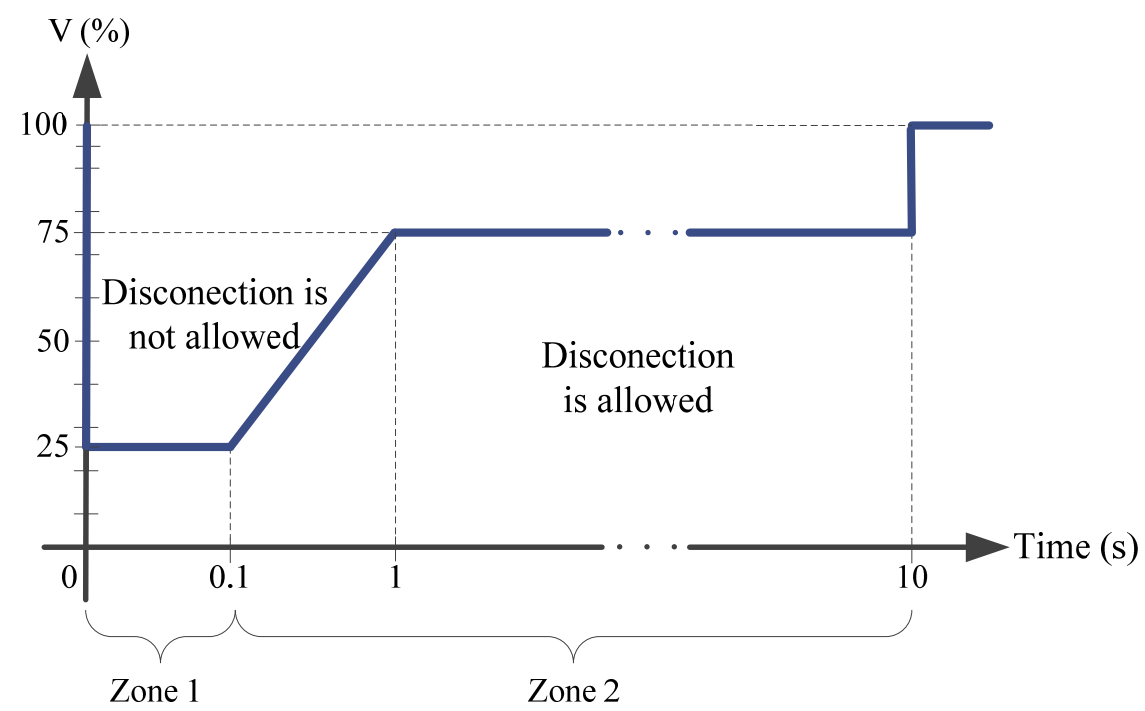

\subsection{Germany}

The LVRT restrictions given by the German grid code [3] establish two different borderlines that the WTG must accomplish to interconnect with the grid (see Figure 2). This paper will study the behavior of the profile given by Borderline 2, due it being the most demanding one. The conditions for this type of voltage dip are:

- Above Borderline 2, all generating facilities must pass through the fault without being disconnected from the network;

- Below Borderline 2, short-time disconnections are always permitted, but the resynchronization must occur after $2 \mathrm{~s}$. Active power feed-in must be increased with a gradient of at least $10 \%$ of the nominal generator capacity per second of the original value;

- For all generating facilities that are not disconnected from the network during a fault, an active power supply must be continued immediately after the fault clearance and increased to the original value with a gradient of at least $20 \%$ of the nominal capacity per second;

- The generating facilities must contribute to the network stability during a voltage dip by means of additional current. For this purpose, a voltage control according to Figure 3 shall be activated 
in the event of a voltage dip of more than $10 \%$ of the effective value of the generator voltage. This voltage control must ensure the supply of a reactive current at the low-voltage side of the generator transformer with a contribution of at least $2 \%$ of the rated current for each percent of the voltage dip. The facilities must be capable of feeding the required current within $20 \mathrm{~ms}$ into the grid. If necessary, a reactive power output of at least $100 \%$ of the rated current must be possible.

Figure 2. LVRT profile in the German grid code.

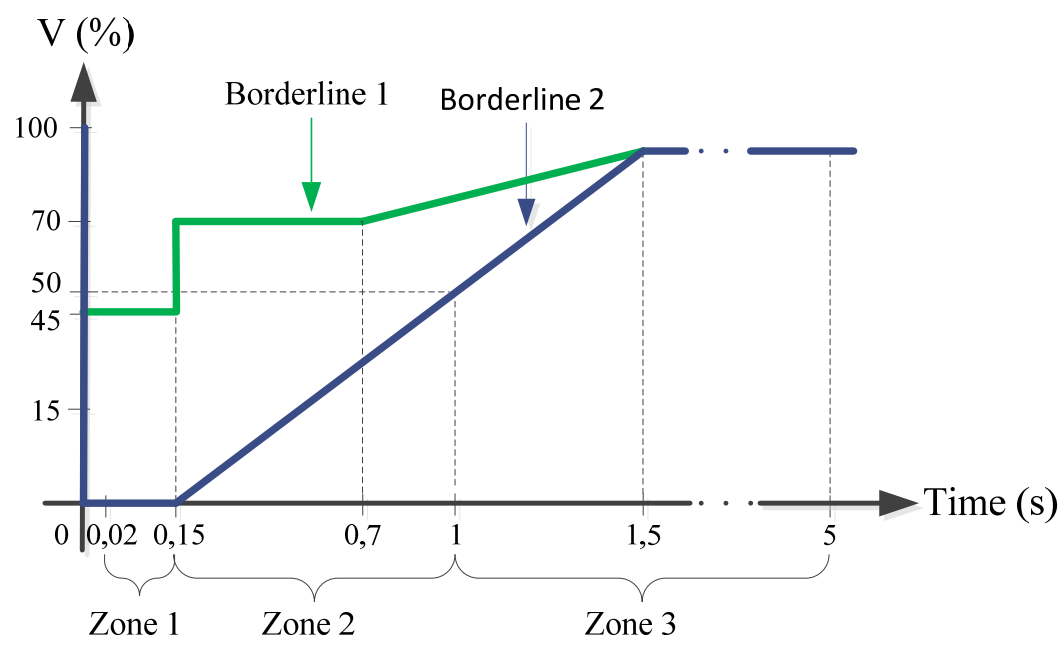

Figure 3. Reactive output current under disturbances according to the German grid code ( $V_{n}$, nominal voltage; $V$, instantaneous voltage during the disturbance; $I_{n}$, nominal current; $I_{r}$, reactive current).

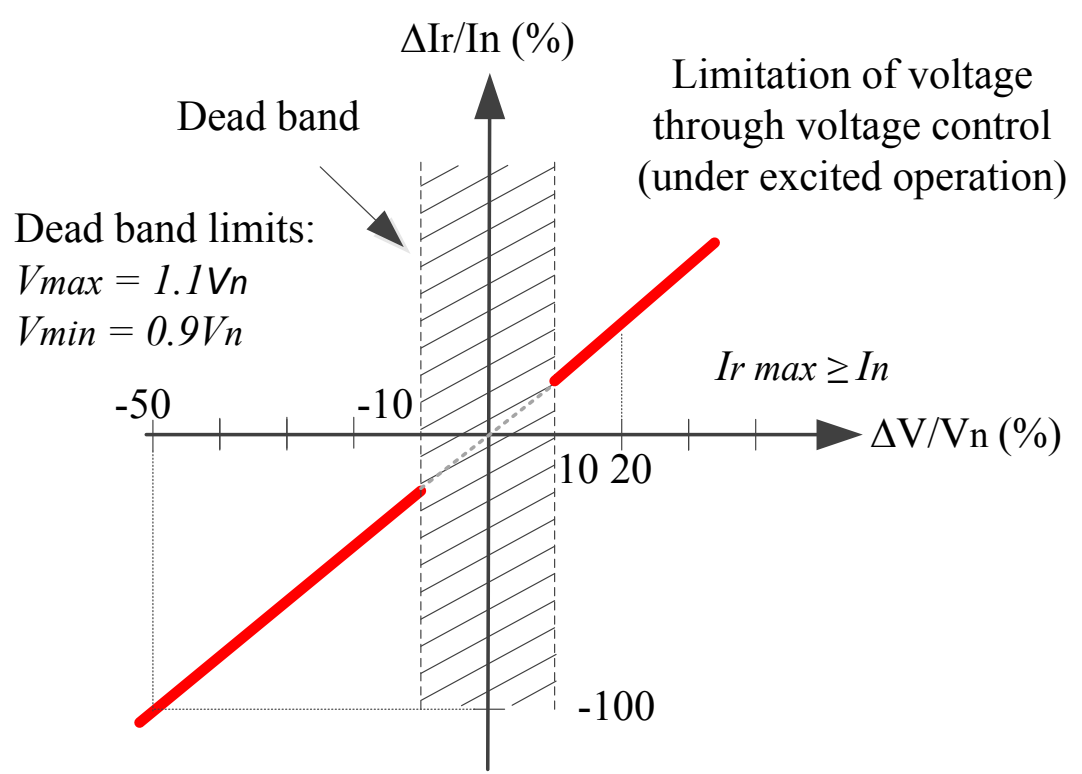




\subsection{Spain}

The LVRT requirements that a WTG must withstand to allow its connection to the Spanish grid are summarized in the operation procedure P.O. 12.3 [7]. In Figure 4a is shown the voltage profile that the WTG must ride through without disconnection, and Figure $4 \mathrm{~b}$ shows the reactive current response during the voltage dip. There are other requirements demanded by the Spanish SO to support the grid; according to these requirements, the LVRT profile is divided into three zones [30] (see Figure 4a):

- Zone 1 starts after the fault and lasts $150 \mathrm{~ms}$;

- Zone 2 is during the fault, between Zone 1 and Zone 3;

- Zone 3 starts when the fault is cleared and the voltage begins to recover to its pre-fault value.

Figure 4. (a) LVRT profile and (b) reactive current response, according to the Spanish grid code.
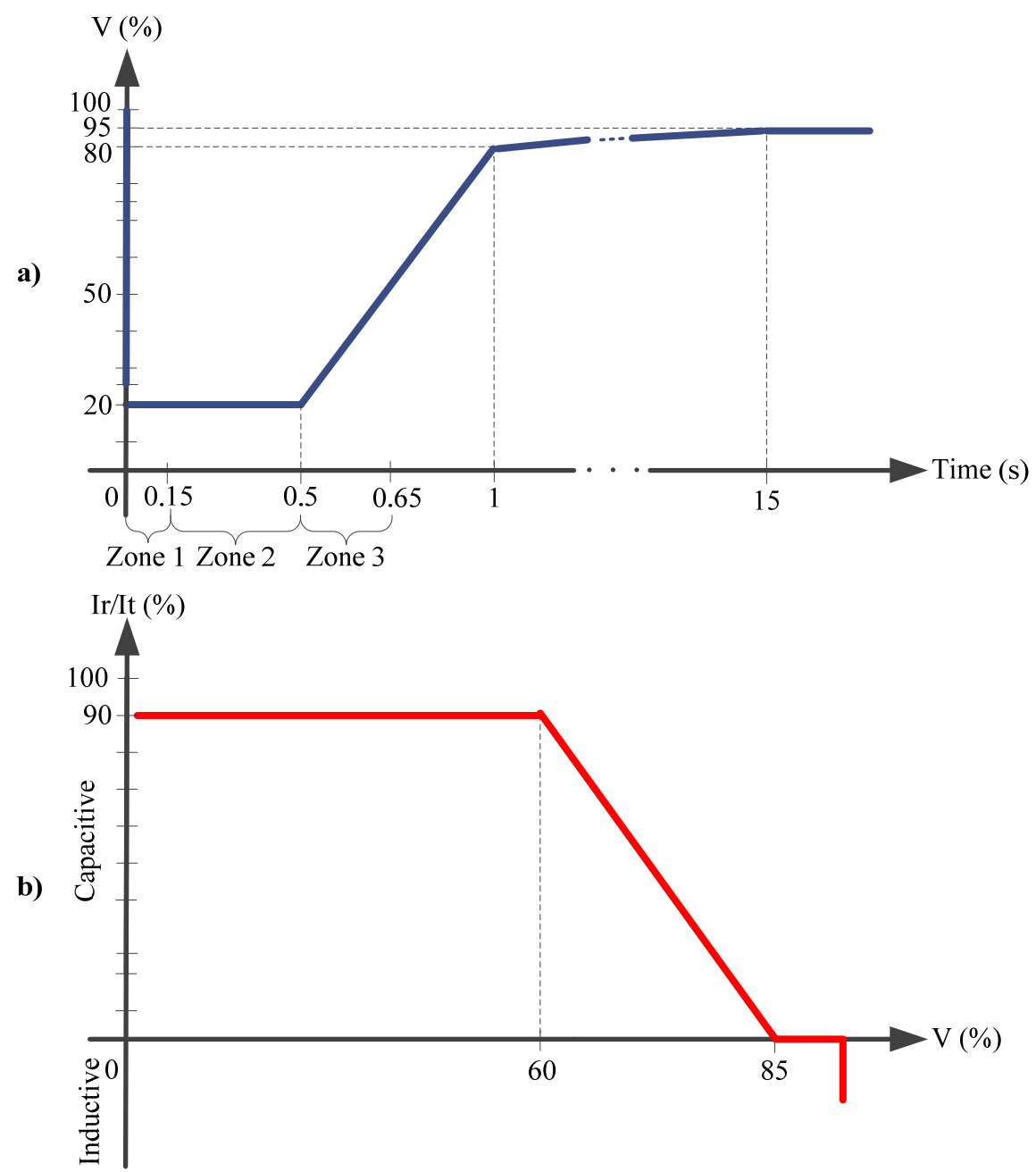

In the Spanish grid code, certain active and reactive power consumption is allowed in all three zones, as shown in Table 1. For example, in Zone 1, during the first $0.35 \mathrm{~s}$, the WTG cannot consume more than the $60 \%$ of the nominal active power. 
Table 1. Active and reactive requirements during three phase faults. WTG, wind turbine generator.

\begin{tabular}{cccc}
\hline Spanish grid code requirements & Zone 1 & Zone 2 & Zone 3 \\
\hline Active power $(P)$ & No limit & $<-10 \% \times P_{n}$ & No limit \\
Reactive power $(Q)$ & $<-60 \% \times P_{n}$ & $<0 \% \times P_{n}$ & No limit \\
Reactive energy $\left(E_{r}\right)$ & No limit & No limit & $<-60 \% \times P_{n} \times 150 \mathrm{~ms}$ \\
Reactive current $\left(I_{r}\right)$ & No limit & $I_{r} / I_{t}>0.9$ (average) & $<-150 \% \times I_{n}$ \\
\hline
\end{tabular}

$P_{n}$, WTG nominal power; $I_{n}$, WTG nominal current; $I_{r}$, reactive current; $I_{t}$, actual current during the fault.

Like the Danish grid code, the Spanish code also demands that the test of the wind turbines must be performed with an equivalent electrical grid described in the procedure for verification and validations (PVVC) [31].

\subsection{U.K.}

The LVRT requirements of the U.K. are divided into two types: short circuit faults up to $140 \mathrm{~ms}$ in duration and voltage dips greater than $140 \mathrm{~ms}$ in duration [5]. This paper studies the behavior subject to short circuits up to $140 \mathrm{~ms}$ in duration, because these are the most demanding. In Figure 5, two different borderlines for short circuits up to $140 \mathrm{~ms}$ are shown. Borderline 1 depicts a fault cleared in $140 \mathrm{~ms}$, and Borderline 2 depicts a fault cleared in less than $140 \mathrm{~ms}$. To enable a comparison with the other grid codes, Borderline 2 was chosen, because the fault time is longer than that of Borderline 1 and is therefore a more demanding requirement.

The technical requirements for these faults demand that each generating unit shall remain transiently stable and connected to the system without tripping for a close-up solid three-phase short circuit fault or any unbalanced short circuit fault for a total fault clearance time of up to $140 \mathrm{~ms}$. Following the fault clearance, the recovery of the grid voltage to $90 \%$ may take longer than $140 \mathrm{~ms}$, as illustrated in Figure 5. The generating unit shall be designed such that after the fault clearance and within $0.5 \mathrm{~s}$ of the restoration of the voltage at the PCC, the active power output shall be restored to at least $90 \%$ of the level available before the fault. During the period of the fault, each generating unit shall generate a maximum reactive current without exceeding the transient rating limit of the generating unit.

Figure 5. LVRT profile in the UK's grid code for short circuits of up to $140 \mathrm{~ms}$ in duration.

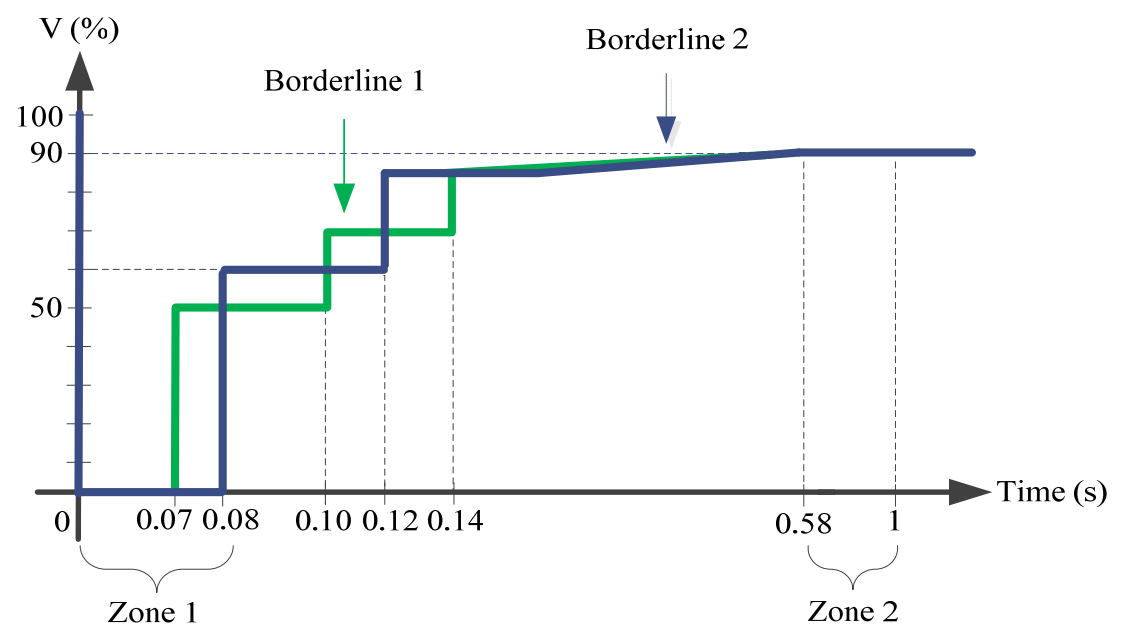




\subsection{Grid Code Summary}

A summary of the different LVRT profiles in the grid codes analyzed in this paper is shown in Figure 6. In Table 2 summarizes the requirements established by the SOs during a voltage dip.

To simplify further analysis and to comply with each of the LVRT requirements, the profiles described are divided in zones; see Table 2.

Figure 6. Comparison of the LVRT profiles of the grid codes summarized.

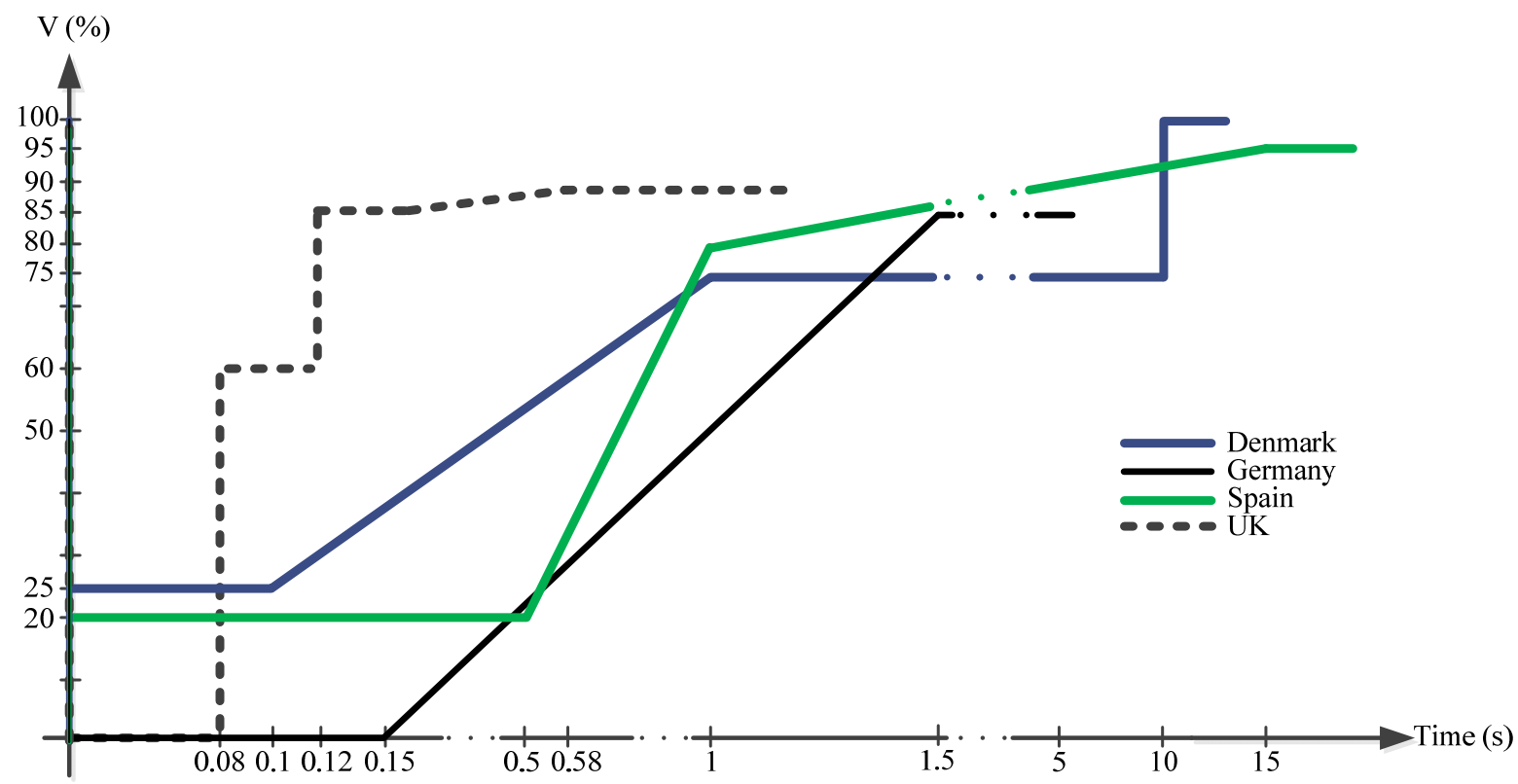

Table 2. Technical characteristics of the LVRT requirements.

\begin{tabular}{|c|c|c|c|c|c|c|c|}
\hline Grid code & $\begin{array}{c}\text { Fault } \\
\text { duration } \\
\text { (ms) }\end{array}$ & $\begin{array}{c}\text { Min voltage } \\
\text { level } \\
\left(\% V_{\text {rated }}\right) \\
\end{array}$ & $\begin{array}{c}\text { Time for } \\
\text { voltage } \\
\text { restoration (s) }\end{array}$ & $\begin{array}{c}\text { Reactive } \\
\text { requirements }\end{array}$ & $\begin{array}{c}\text { Active power } \\
\text { generation }\end{array}$ & $\begin{array}{l}\text { Active power } \\
\text { requirements }\end{array}$ & Analysis zones \\
\hline Denmark & 100 & 25 & 1 & $\begin{array}{l}\text { Consume less } \\
\text { than } I_{r, \text { rated }} \\
\text { during the fault }\end{array}$ & $\begin{array}{l}\text { According to } \\
\text { Equation (1) }\end{array}$ & - & $\begin{array}{c}\text { Zone } 1 \text { and } 2 \\
\text { According to } \\
\text { Figure } 1 \\
\end{array}$ \\
\hline Germany & 150 & 0 & 1.5 & $\begin{array}{c}\text { Within } 20 \mathrm{~ms} \\
\text { according to } \\
\text { Figure } 3\end{array}$ & $\begin{array}{l}\text { After fault } 20 \% \\
\qquad\left(\mathrm{P}_{\text {rated }} / \mathrm{s}\right)\end{array}$ & - & $\begin{array}{c}\text { Zone } 1,2 \text { and } 3 \\
\text { According to } \\
\text { Figure } 2\end{array}$ \\
\hline Spain & 500 & 20 & 1 & $\begin{array}{c}\text { According to } \\
\text { Table } 1\end{array}$ & - & $\begin{array}{c}\text { According to } \\
\text { Table } 1\end{array}$ & $\begin{array}{c}\text { Zone } 1,2 \text { and } 3 \\
\text { According to } \\
\text { Figure } 4 \mathrm{a} \\
\end{array}$ \\
\hline $\begin{array}{c}\text { United } \\
\text { Kingdom }\end{array}$ & 80 & 0 & 0.12 & $\begin{array}{c}\text { Generate } \mathrm{I}_{\mathrm{r}, \text { rated }} \\
\text { during fault }\end{array}$ & $\begin{array}{l}\text { After fault and } \\
\text { within } 0.5 \mathrm{~s} \\
90 \%\left(\mathrm{P}_{\text {rated }}\right) \\
\text { within } 0.5 \mathrm{~s}\end{array}$ & - & $\begin{array}{l}\text { Zone } 1 \text { and } 2 \\
\text { According to } \\
\text { Figure } 5\end{array}$ \\
\hline
\end{tabular}




\section{Wind Turbine and Compensation System Model}

The FSWG to be simulated in this paper is assumed to have the typical configuration shown in Figure 7. In this configuration, the induction generator, the capacitor bank and the compensation system, in this case, the STATCOM, are connected to the low-voltage side of the WTG. The model was implemented in the power system simulation software, PSCAD [32].

Figure 7. Configuration of the system to be analyzed.

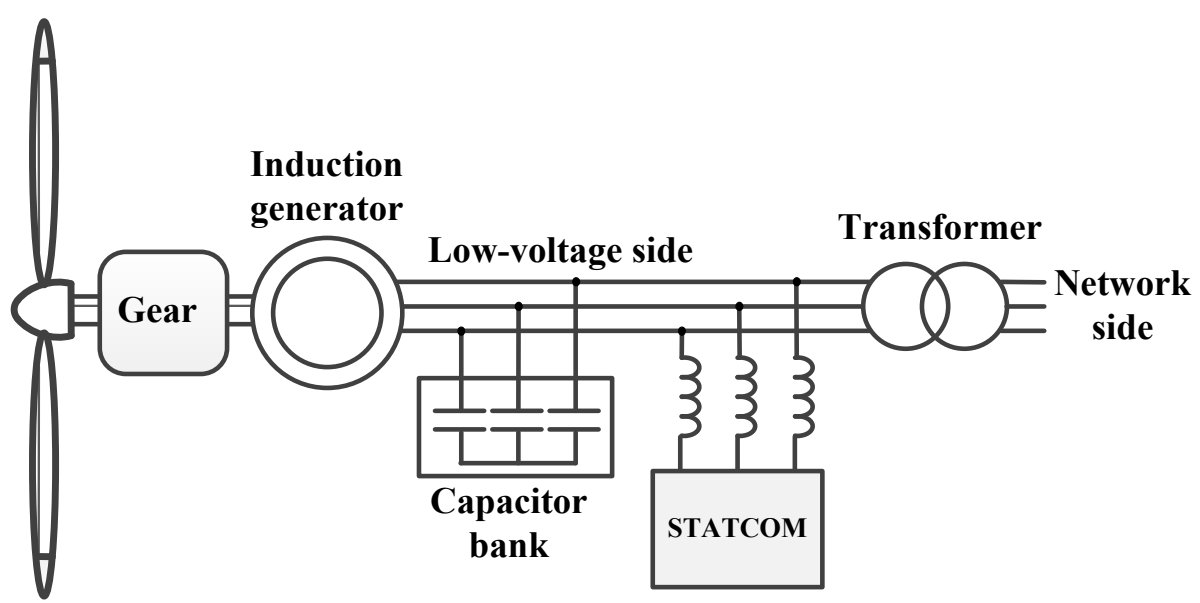

\subsection{Wind Generator}

FSWGs are composed of an induction generator directly connected to the grid through a Low Voltage/Medium Voltage (LV/MV) transformer. FSWGs are modeled in PSCAD [32] by means of a dynamic model for the mechanical elements and a transient model for the generator and power network [33].

The parameters of the WTG used for simulation purposes are shown in Table A3 of Appendix 3, and the power coefficient $\left(C_{p}\right)$ curve given by the manufacturer [34,35] is shown in Figure 8. Additionally, the main parameters of the induction machine are presented in Table A4 of Appendix 3.

Figure 8. WTG power coefficient $C_{p}$.

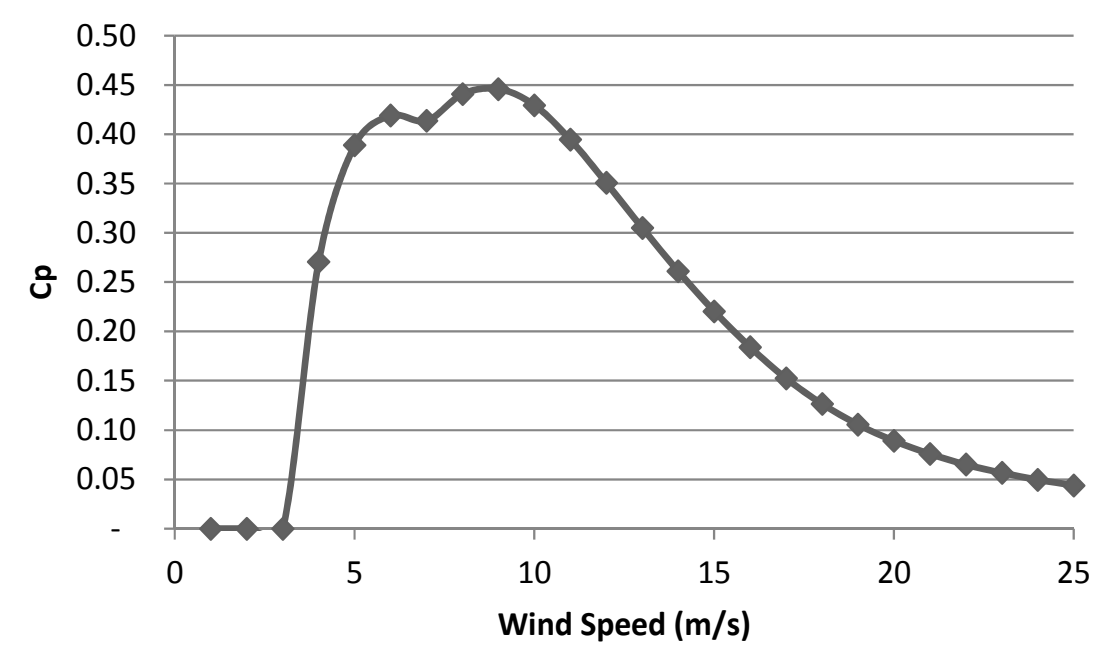




\subsection{STATCOM}

Typically, STATCOMs have been used to provide reactive power at a PCC in a transmission network or distribution network for different purposes, e.g., control of voltage, load compensation and addressing LVRT; the most relevant feature is its capability of injecting a controllable reactive current independent of the grid voltage [17,36-39]. A STATCOM is formed by a DC/AC converter, a capacitor on the DC side and a reactor on the $\mathrm{AC}$ side for filtering the high frequency components related to Insulated Gate Bipolar Transistor (IGBT) commutation. The main function of that capacitor is to help to stabilize the DC voltage (see Figure 9). This power electronic device is based on the voltage source converter principle [40]. Usually, the control implemented for simulation is a Pulse-Width Modulation (PWM) based in dq coordinates that allows the decoupling between the active and the reactive power.

The working limits of the STATCOM are determined by following steady state equations [41]:

$$
\begin{gathered}
P_{S}=\frac{\left|V_{S}\right|\left|V_{L V}\right|}{X_{S}} \sin (\delta) \\
Q_{S}=\frac{\left|V_{S}\right|\left|V_{L V}\right|}{X_{S}} \cos (\delta)-\frac{\left|V_{S}\right|^{2}}{X_{S}}
\end{gathered}
$$

where $V_{S}$ is the voltage at the STATCOM terminals (see terminals $V_{S a}, V_{S b}$ and $V_{S c}$ in Figure 9); $V_{L V}$ is the WTG low-voltage side voltage (see terminals $V_{L V a}, V_{L V b}$ and $V_{L V c}$ in Figure 9); $\delta$ is the phase difference between both voltages; $X_{S}$ is the reactance installed at STATCOM output and $P_{S}$ and $Q_{S}$ are the active and reactive power delivered by the STATCOM, respectively.

The main parameters of the STATCOM used for simulation are presented in Table A5 of Appendix 3.

Figure 9. Typical scheme of a STATCOM based on VSI, voltage source inverter.

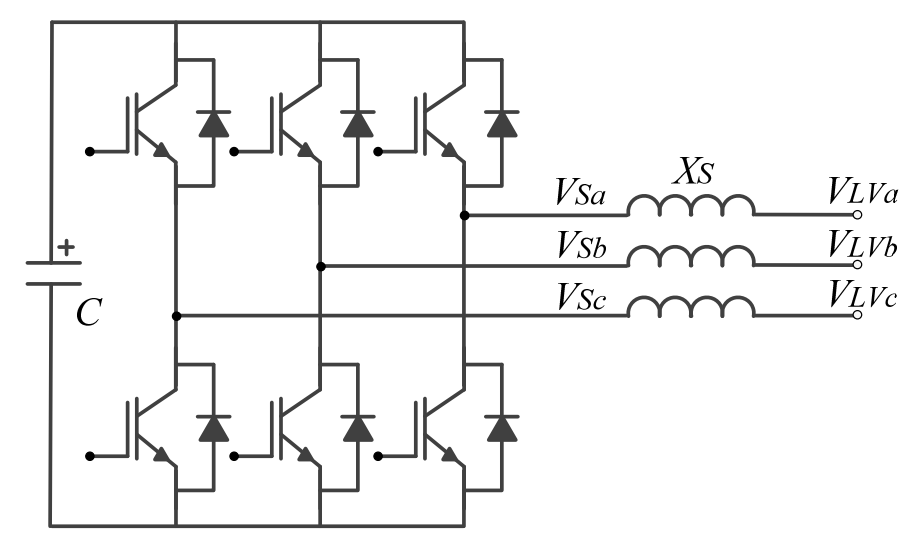

\section{Proposed LVRT Systems Based on STATCOM with Supercapacitors}

STATCOM has many well-known advantages in terms of dynamic stability and reactive current generation regardless of the network voltage, among others. However, one of the main drawbacks of the STATCOM is its low energy storage capability, which limits the active power exchange with the grid $[9,14,16]$. For this reason, in this paper, a compensation system is proposed that takes advantage of the reactive generation capability of the STATCOM and that adds active generation capabilities by adding supercapacitors on the STATCOM DC side. 
In this context, based on the reactive power compensation performed by the STATCOM, it is proposed to analyze the active and reactive power compensation capabilities of two variants of the STATCOM; the STATCOM + ES with an SC and the STATCOM + ES with a DC-DC converter; these with the aim of verifying the compliance of the LVRT requirements.

\subsection{STATCOM + ES}

The active power generation capability of a STATCOM can be increased by adding storage systems to its DC side, such as batteries, SC and flywheels, among others [19-24]. The resulting approach, called STATCOM + ES (energy storage), is usually implemented to smooth the output power [18], electromechanical oscillation damping [42], power flow and, depending on the storage used, even frequency control or inertia emulation [17].

In this paper, it is proposed to use an SC as a storage device, because of its short-time storage capabilities, its high power and energy density, along with the attributes of being low cost, high efficiency, having a fast time response and a long life span [20,21,24,28,43]. All of these features adequately fit the LVRT requirements.

In order to size the $\mathrm{SC}$, the amount of energy $\left(E_{L V R T}\right)$ to be injected during a voltage dip must be calculated. This amount of energy varies depending on the duration of the fault and the profile established by the SO. In this paper, the German grid code has been chosen for SC sizing, because it is the most demanding one. Therefore, the $E_{L V R T}$ is calculated in the following manner [44] (see Figure 10):

$$
E_{\text {LVRT }}=P_{\text {rated }}\left[\left(0.9-V_{\text {min }}\right) t_{1}+0.5\left(t_{2}-t_{1}\right)\left(0.9-V_{\text {min }}\right)\right]
$$

where $P_{\text {rated }}$ is the WTG rated power; $V_{\min }$ is the lowest voltage during the fault (in p.u.); $t_{1}$ is the fault time; and $t_{2}$ is the time for voltage restoration at the PCC.

Figure 10. Energy required during LVRT, German case.

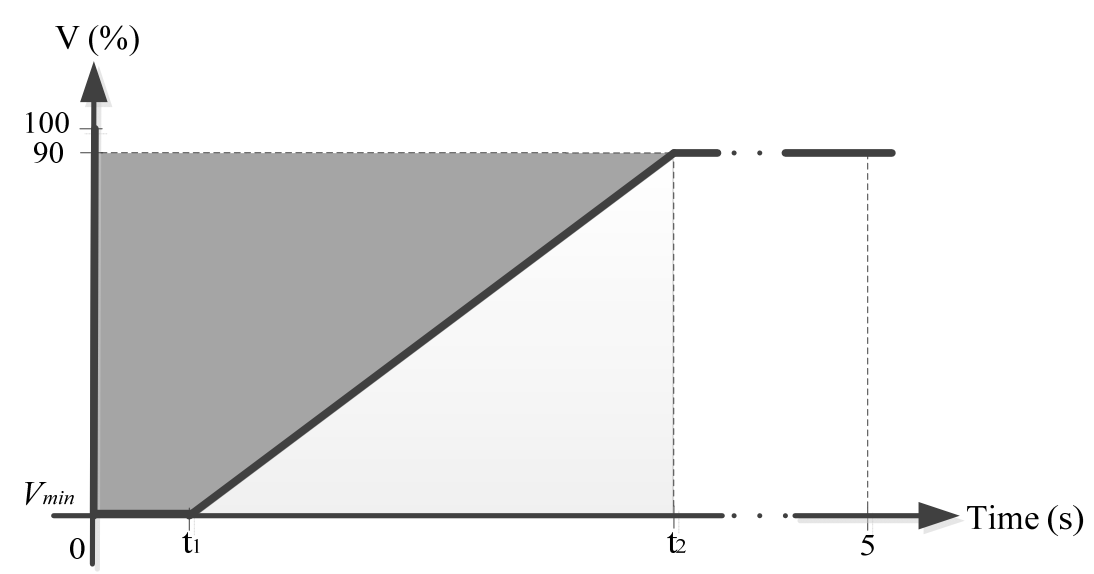

The second step is to calculate the capacitance. The SC has a much larger capacitance per cell than conventional capacitors, but it also has a higher equivalent series resistance (ESR), which means a low efficiency at fast charging/discharging compared to normal capacitors [45]. An SC is usually represented as a capacitor with a series resistance, as described in $[28,44]$ and shown in Figure 11. 
To obtain the capacitance value required to provide the energy calculated using Equation (4), it must be taken into account that the SC cannot be totally discharged. The minimum achievable SOC (state of charge) value is usually approximately $25 \%$, i.e., a reduction of $50 \%$ in voltage, because lower values could affect the control of the converters [46].

Figure 11. Classical model of the supercapacitor. ESR, equivalent series resistance.

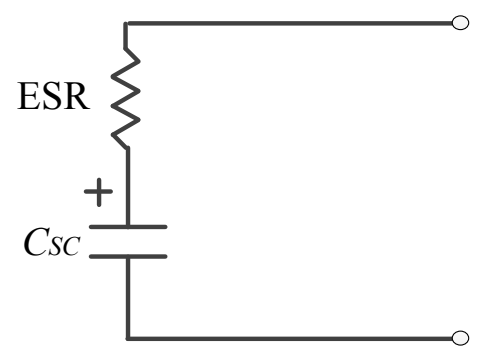

In addition, the power losses in the ESR during the charge and discharge must be considered [47]. To determine the average losses, a set of simulations were performed, as described in Appendix 1, using data from several commercially available SCs. The simulation results indicate that the average losses in the ESR are roughly $10 \%$ of the energy delivered.

Therefore, according to the previous considerations, the capacitance value required for the SC can be written as follows:

$$
C_{S C}=\frac{2 E_{L V R T}}{V_{D C r}^{2}} \frac{1}{\left(1-k_{v \min }^{2}\right)\left(1-k_{\text {loss }}\right)}
$$

where $C S C$ is the capacitance of the SC (in F); $V_{D C r}$ is the rated voltage at the DC bus; kloss is a constant that represents energy losses during the discharge of an SC (in this case, $k_{l o s s}=0.1$ ) and $k_{v \min }$ is the ratio between the minimum voltage and the rated voltage in the DC bus $\left(k_{v \min }=0.5\right)$.

Commercially available SCs usually have maximum voltage $\left(V_{S C r}\right)$ ratings of $200 \mathrm{~V}$; the $C_{S C}$ can be as high as $5000 \mathrm{~F}$, and the ESRs are typically less than $23 \mathrm{~m} \Omega$ (see Appendix 1) [48-50]. SCs can be connected in series to achieve a higher voltage rating and in parallel to increase the capacitance [51]. In this case, the SC modules must be connected in series to achieve a higher voltage rating. Therefore, the final equivalent series capacitance and the total resistance are given by the following:

$$
\begin{aligned}
& N=\frac{V_{D C r}}{V_{S C r}} \\
& C_{S C_{e q}}=\frac{C_{S C}}{N} \\
& E S R_{e q}=N^{*} E S R
\end{aligned}
$$

where $V_{S C r}$ is the SC rated voltage; $N$ is the number of SC modules to be connected in series; $C_{S c e q}$ is the equivalent capacitance; and $E S R_{e q}$ is the equivalent resistance.

In the case of a STATCOM + ES with an SC in the DC link, the ratings selected for the German case are presented in Table A6 from Appendix 3 [50]. The remaining ratings are presented in Table A2 of Appendix 2. 


\subsection{STATCOM + ES with DC-DC Converter}

In this paper, an improvement of the previous system, STATCOM + ES, is also proposed, which consist of adding a bidirectional DC-DC converter between the SC and the STATCOM. This bidirectional DC-DC converter is usually used to achieve a more stable voltage in the DC link; besides, this configuration enables the control of the power flow between the $\mathrm{SC}$ and the grid [26,27,52]. This converter acts in Buck mode to charge the SC and in Boost mode to discharge it and maintain a constant DC link voltage [53,54].

This approach could also be very suitable for short transient disturbances, e.g., voltage dips [25,26]. In [55], a STATCOM + ES with a bidirectional DC-DC converter was used to back up a doubly-fed induction generator with a back-to-back converter during a voltage dip. Therefore, this approach would also be very valuable for the FSWG support during voltage dips. In Figure 12 it is shown that the schematic of the proposed circuit used to back up a WTG during a fault.

Figure 12. STATCOM + ES (energy storage) with a DC-DC converter. SC, supercapacitor.

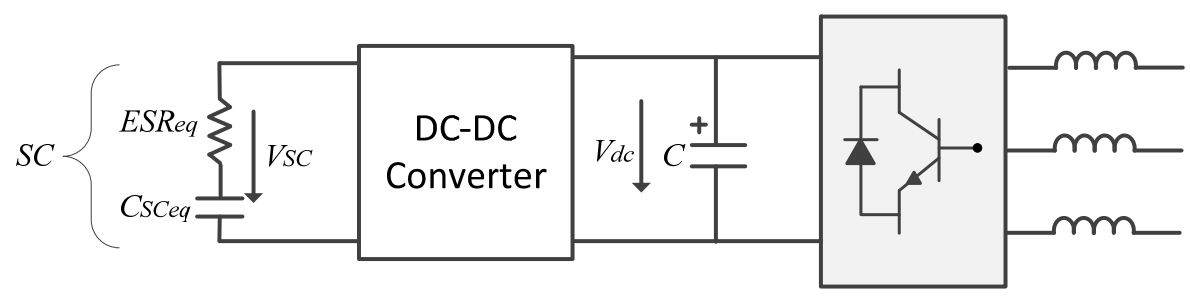

Because the bidirectional converter provides the possibility to control the discharge of the SC without interfering with the DC link of the STATCOM, deeper discharge levels at the SC side are achievable using this configuration. Therefore, the system could provide more active power to the grid. Furthermore, the number of series SC modules required to achieve the DC link voltages could be reduced, depending on the module ratings.

The main parameters used to model the bidirectional DC-DC converter are presented in Table A7 of Appendix 3. Finally, the SC parameters for the German case are presented in Table A8 of Appendix 3.

Note that for each of the different settings, either STATCOM + ES or STATCOM + ES with a DC-DC converter, the SC ratings selected were those more appropriate for the LVRT requirements of each grid code (see Table A2 in Appendix 2).

\section{Control of the Compensation Systems}

The main objectives of the STATCOM controller with an implemented LVRT strategy are to deliver a determined amount of active and reactive power during a voltage dip. The control scheme is based on a voltage-oriented control applied to three phase converters. In order to establish the inner control structure in a rotating dq reference frame, which allows decoupling of the active and reactive power $[15,56]$, it is necessary to analyze the voltage balance across the inductance $\left(L_{S}\right)$ installed at the STATCOM output (see Figure 9). 


$$
\left[\begin{array}{l}
V_{L V a} \\
V_{L V b} \\
V_{L V c}
\end{array}\right]=L_{S} \frac{d}{d t}\left[\begin{array}{c}
i_{S a} \\
i_{S b} \\
i_{S c}
\end{array}\right]+\left[\begin{array}{c}
V_{S a} \\
V_{S b} \\
V_{S c}
\end{array}\right]
$$

where $V_{L V a}, V_{L V b}, V_{L V c}$ are the three phase components of the WTG low-voltage side voltage; $i_{S a}, i_{S b}, i_{S c}$ are the three phase components of the STATCOM current; and $V_{S a}, V_{S b}, V_{S c}$ are the three phase components of the voltage at the STATCOM terminals.

Using Equation (7) and after applying the dq transformation [57], Equation (8) is obtained:

$$
\frac{d}{d t}\left[\begin{array}{c}
I_{S d} \\
I_{S q}
\end{array}\right]=\left[\begin{array}{cc}
\frac{-\omega_{b}}{L} & \omega \\
\omega & \frac{-\omega_{b}}{L}
\end{array}\right]\left[\begin{array}{c}
I_{S d} \\
I_{S q}
\end{array}\right]+\frac{\omega_{b}}{L}\left[\begin{array}{c}
v_{S d}-\left|V_{L V}\right| \\
v_{S q}
\end{array}\right]
$$

where:

- $\omega_{b}$ is the base angular frequency $(2 \pi 50)$;

- $\quad I_{S d}$ and $I_{S q}$ are the direct and quadrature components of the STATCOM current, respectively;

- $\quad V_{S d}$ and $V_{S q}$ are the direct and quadrature components of the STATCOM voltage, respectively;

- $\quad L: \frac{X_{S}}{Z_{\text {base }}}=\frac{\omega_{b} L_{s}}{Z_{\text {base }}} ; Z_{\text {base }}=\frac{V_{\text {base }}}{I_{\text {base }}}$;

- $\quad V_{b a s e}$ and Ibase are the rated line voltage and nominal current, respectively (see Table A4 of Appendix 3);

- $\quad \omega$ is the reference frame rotating at the grid frequency;

- $\left|V_{L V}\right|$ is the magnitude of the WTG low-voltage side voltage.

Equation (8), leads to a rule that allows decoupling $I_{S d}$ and $I_{S q}$. The inverter voltage vector is controlled as follows:

$$
\begin{gathered}
v_{S d}=\frac{L}{\omega_{b}}\left(c_{1}-\omega I_{q}\right)+\left|V_{L V}\right| \\
v_{S q}=\frac{L}{\omega_{b}}\left(c_{2}+\omega I_{d}\right)
\end{gathered}
$$

where $c_{1}$ and $c_{2}$ are the proportional plus integral (PI) controllers, defined next.

Replacing Equations (9) and (10) in Equation (8), the following equation is obtained:

$$
\frac{d}{d t}\left[\begin{array}{c}
I_{S d} \\
I_{S q}
\end{array}\right]=\left[\begin{array}{cc}
\frac{-\omega_{b}}{L} & \omega \\
\omega & \frac{-\omega_{b}}{L}
\end{array}\right]\left[\begin{array}{c}
I_{S d} \\
I_{S q}
\end{array}\right]+\left[\begin{array}{l}
c_{1} \\
c_{2}
\end{array}\right]
$$

Equation (11) shows that $I_{S d}$ and $I_{S q}$ respond to $c_{1}$ and $c_{2}$, respectively, through a first order transfer function, with no cross-coupling. The control rule for Equations (9) and (10) is completed by defining the feedback loops and PI compensation as follows: 


$$
\begin{aligned}
& c_{1}=\left(k_{p 1}+\frac{k_{i 1}}{s}\right)\left(I_{S d, r e f}-I_{S d}\right) \\
& c_{2}=\left(k_{p 1}+\frac{k_{i 1}}{s}\right)\left(I_{S q, r e f}-I_{S q}\right)
\end{aligned}
$$

Then, the control system block diagram for the inner control structure is shown in Figure 13, for which all of the variables are in a dq reference frame after applying the dq transformation [57]. As a result, the inputs variables are the STATCOM current in dq coordinates ( $I_{S d}$ and $I_{S q}$ ) and the voltage $V_{L V}$ at the FSWG low-voltage side. The reference variables are those for the STATCOM current, ISd,ref and $I_{S q, r e f}$.

Figure 13. Block diagram of the inner vector control technique implemented in the STATCOM. PI, proportional plus integral.

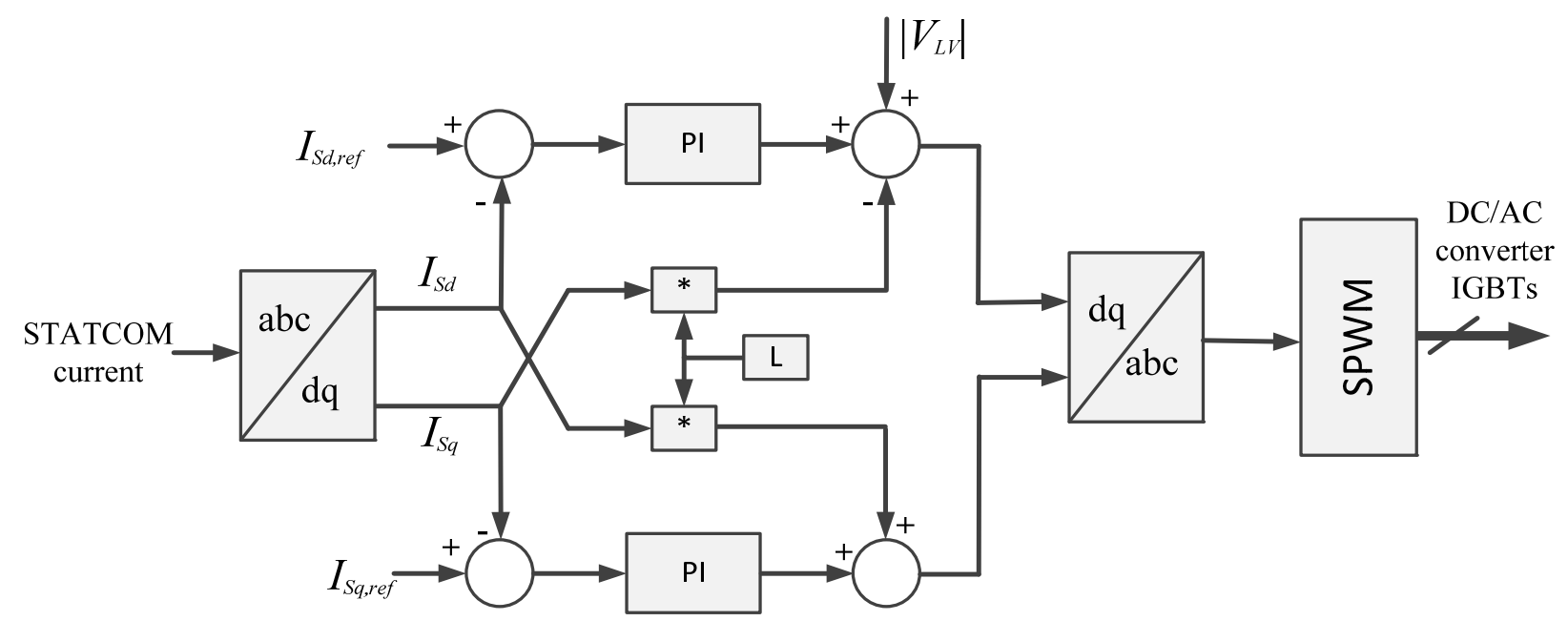

This inner control is set to deliver the voltage references to the SPWM (Sinusoidal Pulse Width Modulation) to fire the IGBTS that control the STATCOM DC/AC converter. The outer control loops are generally designed to maintain the DC voltage to compensate for the converter losses and the voltage at the low-voltage side to control the flow of reactive power between the STATCOM and the power network [56].

The outer control loops proposed in this paper are a cascade of PIs set to operate under two different situations. When the grid is operating normally, the outer control loop is set to follow the references to maintain the DC link voltage $V_{d c}$ at a reference value $V_{d c, \text { ref }}$ and to control the reactive power injected by the STATCOM, i.e., $Q_{s}$ and $Q_{s, r e f}$ (see the N/O blocks in Figure 14). However, when the grid is under the fault condition, the direct axis outer control loop is set to maintain the DC link voltage at a constant level through a faster PI, and the quadrature outer control loop is set to maintain the rated low-voltage side voltage $V_{L V, r e f}$ (see fault blocks in Figure 14). The outer control structure is shown in Figure 14 . The target of these separate controllers is to provide adequate references to the inner control loop to deliver the necessary amount of active and reactive power to back up the FWSG under a voltage dip. Note that the overall control structure is achieved by combining the blocks shown in Figures 13 and 14. 
Figure 14. Block diagram of the outer control technique implemented in the STATCOM. $(\mathrm{N} / \mathrm{O}=$ normal operation, Fault $=$ fault condition $)$.

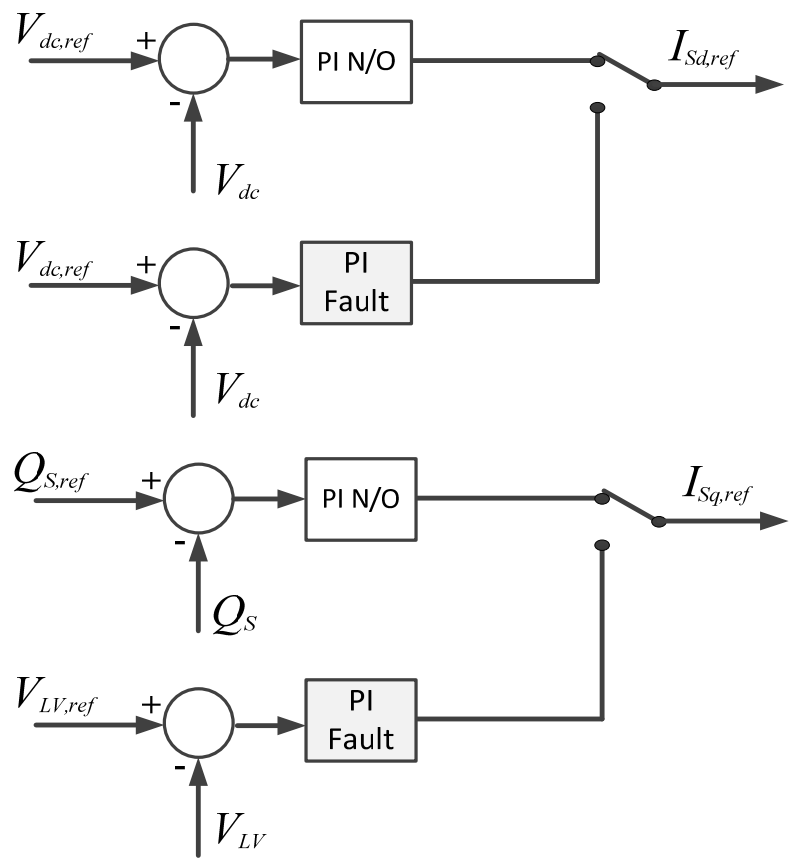

Recall that the main objective of this paper is to explore the capabilities of a STATCOM with SCs in its DC side. To enable this exploration, classical PI controllers are chosen here.

\section{Simulations Scenarios}

In this section, the simulation results of the operation of the FSWG with and without the compensation of the STATCOM under voltage dips and the requirements of the grid codes of Denmark, Germany, Spain and the UK are presented and discussed.

Four different LVRT requirements are simulated under the following scenarios:

- FSWG: FSWG in its standard configuration, i.e., directly connected to the grid. In this case, the capacitor bank of the WTG, commonly used for power factor correction, is disconnected;

- FSWG + STATCOM: FSWG with a shunt-connected STATCOM for reactive and LVRT purposes;

- $\quad$ FSWG + STATCOM + ES: FSWG with a STATCOM + ES that includes an SC in the DC link;

- $\mathrm{FSWG}+\mathrm{STATCOM}+\mathrm{ES}+(\mathrm{DC} / \mathrm{DC})$ : FSWG with a STATCOM + ES with the SC connected through a DC-DC converter.

In total, 20 simulations are performed to study the behavior of the FSWG under different LVRT requirements. All simulations were performed with the WTG running at its rated power.

Note that, unlike the other grid codes, the Spanish grid code demands that WTGs must withstand the profile shown in Figure 4 during a test, or if a simulation test is performed, the system must be simulated using the equivalent electrical grid described in the PVVC [31]. For this reason, it was necessary to perform two simulations, the first one using the equivalent electrical grid, in which a three-phase fault 
that lasts $150 \mathrm{~ms}$ was simulated, and the second one implemented according to the profile presented in the P.O. 12.3 shown in Figure 4.

To simulate the voltage dips, a three-phase fault is introduced according to the profile of each grid code. The operation of the system without the capacitor bank and STATCOM compensation (Scenario 1) is simulated to represent the worst scenario. Scenarios 2, 3 and 4 are performed with a shunt STATCOM connected; in this case, the objectives of the STATCOM controller during normal operation are to achieve zero reactive power injection at the PCC and to maintain the voltage in the DC link at its rated value. The target during a voltage dip is to fulfill the LVRT requirements and, in a generic way, to minimize the voltage variations in the DC link.

As an example, for the sake of simplicity and because the German requirements appear to be the most demanding ones, the response of the FSWG under the German's SO requirements are shown in Figure 15. Note that the simulations are divided into zones, as explained in Table 2. In Section 7, the results for the remaining simulations are summarized.

Figure 15. WTG response under German LVRT requirements. NC, results without a STATCOM; S, results with a STATCOM; SC, results with a STATCOM + ES (SC in the DC link); SC DC-DC, results with a STATCOM + ES and a DC-DC converter in the DC link.
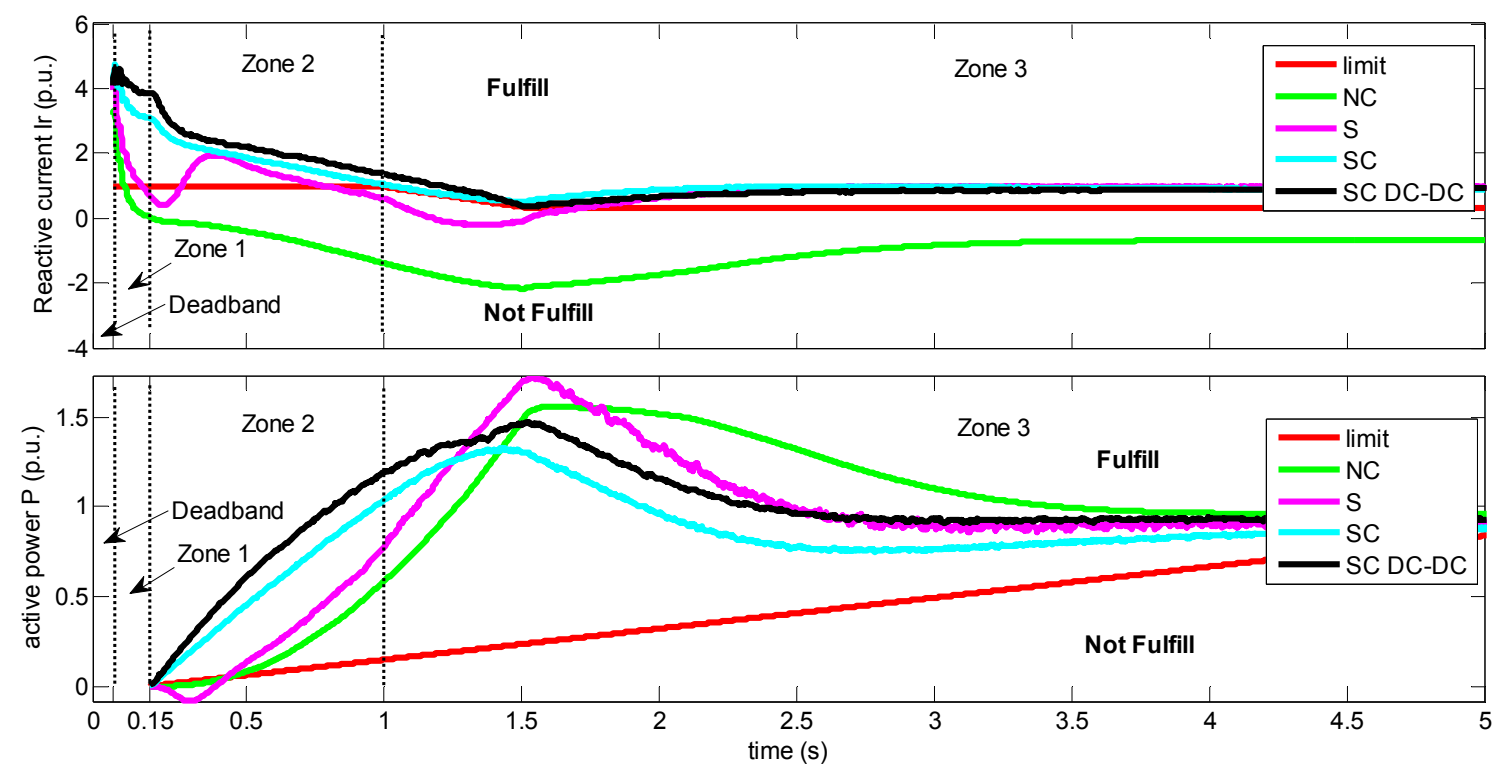

The following nomenclature is used in the following figures:

- Lim: Limit of the variable, active power $P$ or reactive current $I_{r}$;

- NC: results without a STATCOM;

- $\quad$ S: results with a STATCOM;

- $\quad \mathrm{SC}$ : results with a STATCOM + ES (SC in the DC link);

- SC DC-DC: results with a STATCOM + ES and a DC-DC converter in the DC link.

The worst possible scenario is depicted with the NC label, as shown in Figure 15. The sudden reduction of the voltage in the grid leads to an important reactive current consumption in the PCC. As shown in the figure, this requirement is not being fulfilled in any of the marked zones of the German 
grid code. This behavior could lead to an overall instability and cause the disconnection of the WTG, which is currently an unacceptable performance of any WTG according to grid codes.

The next scenario is simulated with the same grid fault, but in this case, the WTG is supported by a STATCOM. In this case, as previously explained, the STATCOM is controlled to compensate for the reactive power in the grid. When the control senses the fault, the STATCOM starts injecting reactive current into the grid to comply with the grid codes (see Figure 15). Note that, in this scenario, the reactive current requirement is close to that demanded in the code. The clear drawback of this possible solution is that the FSWG is not able to fulfill the grid codes. It is important to notice that, in this case, the active power requirement in Zone 2 is not being fulfilled, because of the lack of the STATCOM's capability of active power generation.

Next, following the same procedure, the grid fault is introduced, but this time, the FSWG is being supported by a STATCOM + ES. This variant was set up to fully comply with the German grid code. The important difference in this case is that, as a result of a larger storage device, i.e., an SC, the WTG is now able to deliver the required amount of reactive current and is also able to deliver the required active power demanded in Zone 2, as shown in Figure 15.

Finally, after noting the advantages of including a higher storage device in the DC link of the STATCOM, a shunt DC-DC converter was installed in the DC link of the STATCOM + ES to enable control of the SC discharge, thereby supplying more active power to the grid. As a result, when the STATCOM + ES with a DC-DC converter is supporting the FSWG under voltage dips, it was also possible to comply with the grid codes, but this time with an improved active power response, as shown in Figure 15.

To enhance the understanding of and to provide an indication of the influence in the grid of the STATCOM + ES with the DC-DC converter with respect to the STATCOM and STATCOM + ES, in Figures 16-20, the evolution during the voltage dip of the most important variables are shown.

Figure 16. Reactive current evolution through the voltage dip, German case.

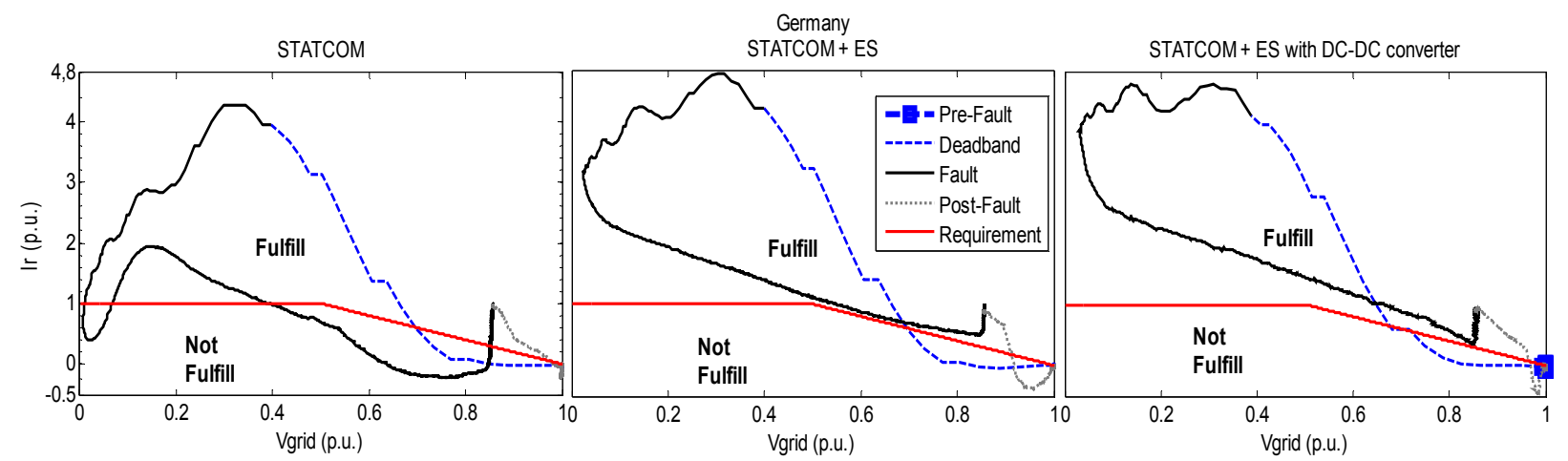

The evolution of the reactive current in the grid, before, during and after the fault is shown in Figure 16. The solid black line corresponds to the reactive current behavior in the analysis zones, and the red one corresponds to the requirements. Note that the reactive current requirement is being fulfilled by means of the STATCOM + ES and STATCOM + ES with the DC-DC converter. 
Figure 17. Active power evolution through the voltage dip, German case.

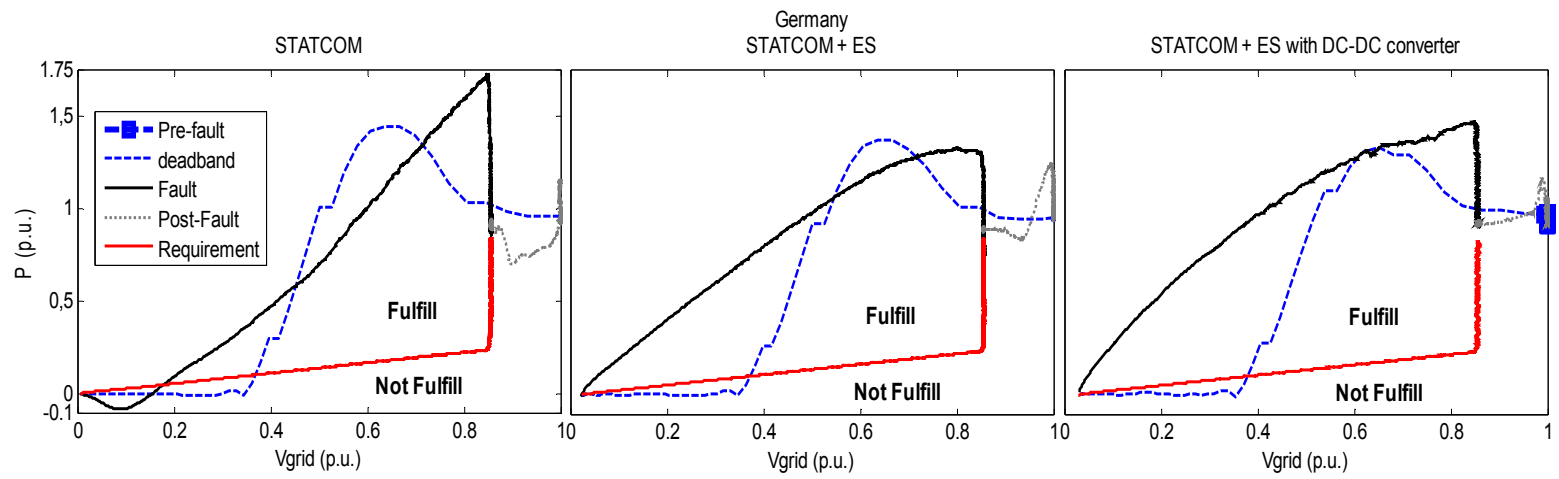

Figure 18. STATCOM active power evolution through the voltage dip, German case.

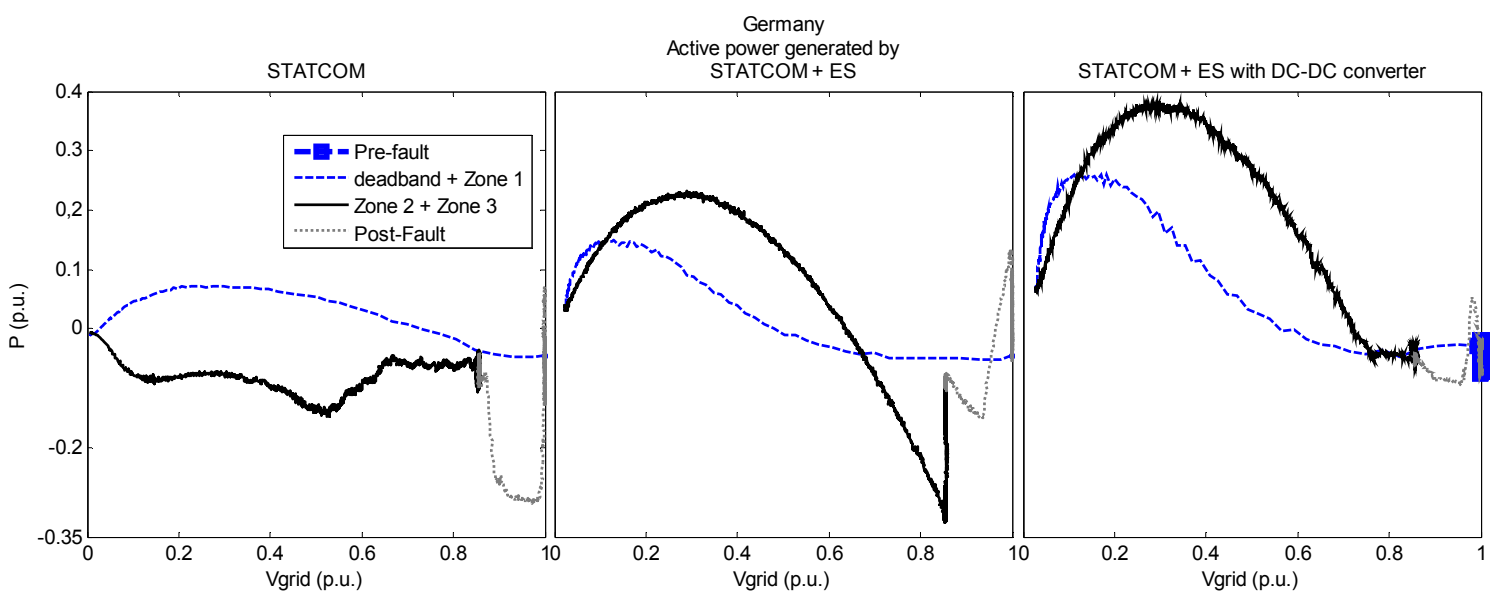

Figure 19. STATCOM reactive power evolution through the voltage dip, German case.

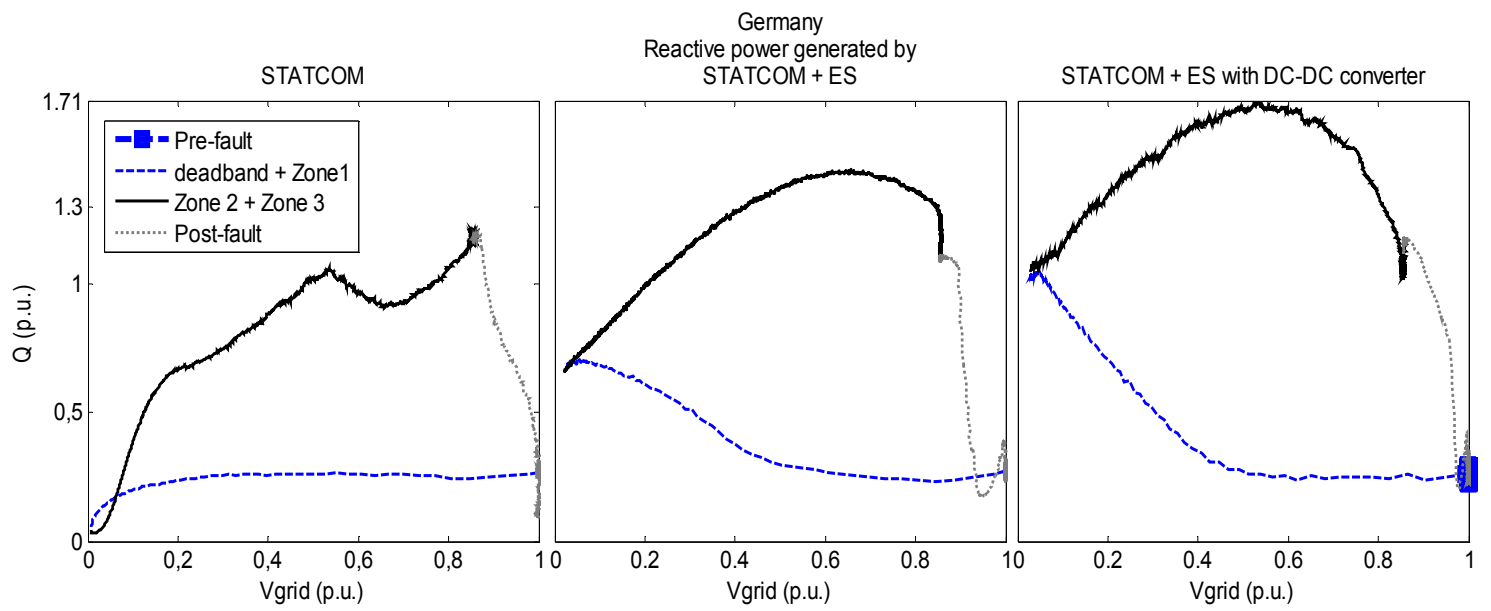


Figure 20. DC link voltage and DC-DC converter voltage in the SC during voltage dip, German case.

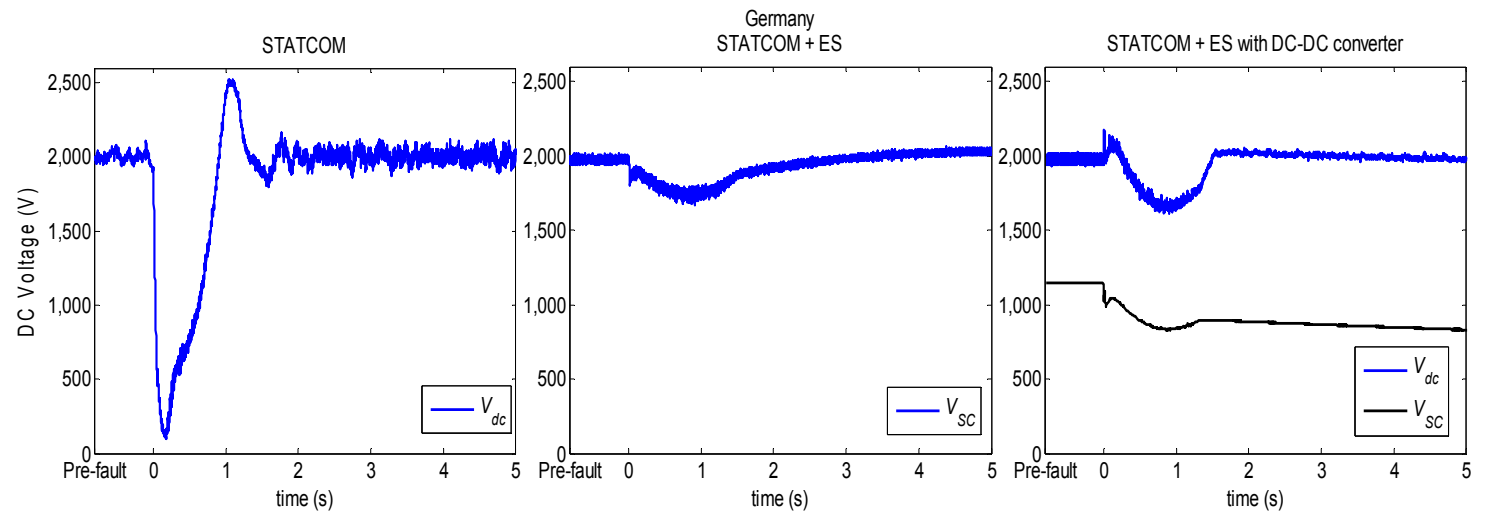

Similarly, in Figure 17, the active power evolution and requirements in the German grid code are shown. Here, a clear active power enhancement of the active power response in the grid is observed. Once again, the solid black line corresponds to the active power behavior in the analysis zones, and the red line corresponds to the requirement.

The active and reactive power injection responses for the different configurations (STATCOM, STATCOM + ES and STATCOM + ES with DC-DC converter) are shown in Figures 18 and 19. In Figure 18, the improvement achieved by means of the inclusion of a supercapacitor in the DC link is observed. Finally, in Figure 20 is shown the evolution of the voltage in the DC link and the SC during the voltage dip.

\section{Summary of Results}

In Section 6, the behavior of the FSWG under the requirements of the German's SO was presented. To simplify the analysis and summarize the results, in Tables 3 and 4 present the results of the previous section. The minimum result obtained in each zone per simulation and its corresponding requirement are presented. The tables are divided per country and per zone; in each box is presented the requirement in brackets and above it, the result. The zones without requirement are denoted as not available (N/A). Finally, green values denote fulfillment and red values are those where the specific requirement is not fulfilled.

The results for the FSWG simulation in the worst case scenario are presented in Table 3, which summarizes the behavior of the FSWG during the voltage dip without the capacitor bank. In this case, the WTG is unable to fulfill almost any of the reactive current requirements; therefore, this appears to be the most demanding requirement.

The results for the simulation of the FSWG with the shunt STATCOM, STATCOM + ES and STATCOM + ES with DC-DC are summarized in Tables 3 and 4. With only the STATCOM contribution, the requirements of the Danish and Spanish grid codes are fulfilled (see Table 3). The UK's requirements are not fulfilled during the first $10 \mathrm{~ms}$ of the fault, because the UK's grid code demands that the generation units shall inject the maximum reactive current during the fault without a deadband, which is allowed by the other grid codes (e.g., the German grid code demands that the WTG must respond to the reactive current requirement within $20 \mathrm{~ms}$ [3]). Note that with a proper deadband, it would be possible to fulfill all of the UK's requirements with the addition of a STATCOM alone. 
Table 3. Results and requirements, in p.u., of the different grid codes, without a capacitor bank and with a STATCOM. Requirements are shown in brackets, red values are those where the specific requirement is not fulfilled and N/A means not available. PVVC, procedure for verification and validations.

\begin{tabular}{|c|c|c|c|c|c|c|c|c|c|c|c|c|c|c|}
\hline & \multirow{3}{*}{$\begin{array}{c}\text { Country } \\
\text { Zone } \\
\end{array}$} & \multirow{2}{*}{\multicolumn{2}{|c|}{ Denmark }} & \multirow{2}{*}{\multicolumn{3}{|c|}{ Germany }} & \multicolumn{6}{|c|}{ Spain } & \multirow{2}{*}{\multicolumn{2}{|c|}{ UK }} \\
\hline & & & & & & & \multicolumn{3}{|c|}{ PVVC } & \multicolumn{3}{|c|}{ P.O. 12.3 } & & \\
\hline & & 1 & 2 & 1 & 2 & 3 & 1 & 2 & 3 & 1 & 2 & 3 & 1 & 2 \\
\hline \multirow{4}{*}{ 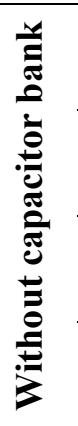 } & Active power & $\begin{array}{c}\mathbf{0 . 1 2 8} \\
(0.101) \\
\end{array}$ & $\begin{array}{c}\mathbf{0 . 1 1 8} \\
(0.101) \\
\end{array}$ & N/A & $\begin{array}{c}-3.72 \times 10^{-6} \\
(0.00017)\end{array}$ & $\begin{array}{c}\mathbf{0 . 5 7 7} \\
(0.148) \\
\end{array}$ & N/A & $\begin{array}{c}\mathbf{0 . 0 6 9} \\
(0.1) \\
\end{array}$ & N/A & N/A & $\begin{array}{c}\mathbf{0 . 0 6 4} \\
(0.1) \\
\end{array}$ & $\mathrm{N} / \mathrm{A}$ & N/A & $\begin{array}{l}\mathbf{1 . 0 0 1} \\
(0.9) \\
\end{array}$ \\
\hline & $\begin{array}{c}\text { Reactive } \\
\text { current }\end{array}$ & $\begin{array}{c}-\mathbf{0 . 5 8 8} \\
(-1.0)\end{array}$ & $\begin{array}{c}-1.782 \\
(-1.0)\end{array}$ & $\begin{array}{l}\mathbf{0 . 0 6 1} \\
(1.0)\end{array}$ & $\begin{array}{c}-1.381 \\
(1.0) \\
\end{array}$ & $\begin{array}{c}\mathbf{2 . 1 6 6} \\
(0.30378)\end{array}$ & N/A & $\begin{array}{l}-\mathbf{0 . 5 6 3} \\
(0.015)\end{array}$ & $\begin{array}{c}-2.468 \\
(-1.5)\end{array}$ & N/A & $\begin{array}{c}\mathbf{0 . 6 2 6} \\
(0.015)\end{array}$ & $\begin{array}{c}-\mathbf{0 . 7 4 7} \\
(-1.5)\end{array}$ & $\begin{array}{c}-0.588 \\
(1.0)\end{array}$ & N/A \\
\hline & Reactive power & $\mathrm{N} / \mathrm{A}$ & N/A & N/A & N/A & N/A & $\begin{array}{c}-\mathbf{0 . 5 8 2} \\
(-0.6)\end{array}$ & $\begin{array}{c}-\mathbf{0 . 0 4 9} \\
(0)\end{array}$ & N/A & $\begin{array}{c}-\mathbf{0 . 5 8 3} \\
(-0.6)\end{array}$ & $\begin{array}{c}-0.063 \\
(0)\end{array}$ & $\mathrm{N} / \mathrm{A}$ & N/A & N/A \\
\hline & Reactive energy & $\mathrm{N} / \mathrm{A}$ & N/A & N/A & N/A & N/A & N/A & N/A & $\begin{array}{c}-1.058 \\
(-0.6)\end{array}$ & N/A & N/A & $\begin{array}{c}-\mathbf{0 . 1 5 3} \\
(-0.6)\end{array}$ & N/A & N/A \\
\hline \multirow{4}{*}{ 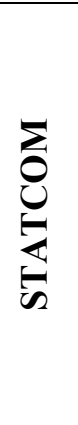 } & Active power & $\begin{array}{c}\mathbf{0 . 1 6 5} \\
(0.101) \\
\end{array}$ & $\begin{array}{c}\mathbf{0 . 1 6 1} \\
(0.101) \\
\end{array}$ & N/A & $\begin{array}{c}-0.0834 \\
(0.00017)\end{array}$ & $\begin{array}{c}\mathbf{0 . 7 6 6} \\
(0.148) \\
\end{array}$ & N/A & $\begin{array}{c}-\mathbf{0 . 0 6 7} \\
(0.1)\end{array}$ & N/A & N/A & $\begin{array}{c}\mathbf{0 . 0 5 7} \\
(0.1) \\
\end{array}$ & $\mathrm{N} / \mathrm{A}$ & N/A & $\begin{array}{r}\mathbf{1 . 0 0 1} \\
(0.9) \\
\end{array}$ \\
\hline & $\begin{array}{c}\text { Reactive } \\
\text { current }\end{array}$ & $\begin{array}{c}-\mathbf{0 . 0 1 4} \\
(-1.0)\end{array}$ & $\begin{array}{r}-\mathbf{0 . 5 9 5} \\
(-1.0)\end{array}$ & $\begin{array}{c}0.741 \\
(1.0) \\
\end{array}$ & $\begin{array}{c}\mathbf{0 . 3 9 4} \\
(1.0) \\
\end{array}$ & $\begin{array}{c}-\mathbf{0 . 2 1 7} \\
(0.30378) \\
\end{array}$ & N/A & $\begin{array}{c}\mathbf{0 . 8 0 7} \\
(0.015) \\
\end{array}$ & $\begin{array}{r}-1.213 \\
(-1.5)\end{array}$ & N/A & $\begin{array}{c}\mathbf{0 . 4 1 6} \\
(0.015) \\
\end{array}$ & $\begin{array}{r}-\mathbf{0 . 3 7 5} \\
(-1.5)\end{array}$ & $\begin{array}{c}-0.015 \\
(1.0) \\
\end{array}$ & N/A \\
\hline & Reactive power & N/A & N/A & N/A & N/A & N/A & $\begin{array}{c}-\mathbf{0 . 0 1 5} \\
(-0.6)\end{array}$ & $\begin{array}{c}\mathbf{0 . 1 3 8} \\
(0)\end{array}$ & N/A & $\begin{array}{c}-\mathbf{0 . 0 1 8} \\
(-0.6)\end{array}$ & $\begin{array}{c}\mathbf{0 . 0 4 9 8} \\
(0)\end{array}$ & N/A & N/A & N/A \\
\hline & Reactive energy & N/A & N/A & N/A & N/A & N/A & N/A & N/A & $\begin{array}{c}-\mathbf{0 . 3 3 6} \\
(-0.6)\end{array}$ & N/A & N/A & $\begin{array}{c}-\mathbf{0 . 0 3 6} \\
(-0.6)\end{array}$ & N/A & N/A \\
\hline
\end{tabular}


Table 4. Results and requirements, in p.u., of the different grid codes, with a STATCOM + ES and with a STATCOM + ES with DC-DC converter. Requirements are shown into brackets, red values are those where the specific requirement is not fulfilled and N/A means not available.

\begin{tabular}{|c|c|c|c|c|c|c|c|c|c|c|c|c|c|c|}
\hline & \multirow{3}{*}{$\begin{array}{c}\text { Country } \\
\text { Zone }\end{array}$} & \multirow{2}{*}{\multicolumn{2}{|c|}{ Denmark }} & \multirow{2}{*}{\multicolumn{3}{|c|}{ Germany }} & \multicolumn{6}{|c|}{ Spain } & \multirow{2}{*}{\multicolumn{2}{|c|}{ UK }} \\
\hline & & & & & & & \multicolumn{3}{|c|}{ PVVC } & \multicolumn{3}{|c|}{ P.O. 12.3} & & \\
\hline & & 1 & 2 & 1 & 2 & 3 & 1 & 2 & 3 & 1 & 2 & 3 & 1 & 2 \\
\hline \multirow{4}{*}{ 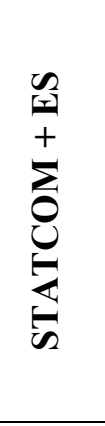 } & Active power & $\begin{array}{c}\mathbf{0 . 1 7 2} \\
(0.101)\end{array}$ & $\begin{array}{c}\mathbf{0 . 1 5 3} \\
(0.101)\end{array}$ & $\mathrm{N} / \mathrm{A}$ & $\begin{array}{c}\mathbf{0 . 0 0 4} \\
(0.00017)\end{array}$ & $\begin{array}{c}\mathbf{0 . 7 4 7} \\
(0.148)\end{array}$ & N/A & $\begin{array}{c}\mathbf{0 . 0 3 1} \\
(0.1)\end{array}$ & N/A & N/A & $\begin{array}{c}\mathbf{0 . 0 9 1} \\
(0.1)\end{array}$ & N/A & N/A & $\begin{array}{c}\mathbf{0 . 9 8 8} \\
(0.9)\end{array}$ \\
\hline & Reactive current & $\begin{array}{c}-\mathbf{0 . 0 1 8} \\
(-1.0)\end{array}$ & $\begin{array}{c}-\mathbf{0 . 3 1 9} \\
(-1.0)\end{array}$ & $\begin{array}{r}3.092 \\
(1.0)\end{array}$ & $\begin{array}{c}\mathbf{1 . 0 4 3} \\
(1.0) \\
\end{array}$ & $\begin{array}{c}\mathbf{0 . 4 9 2} \\
(0.30378) \\
\end{array}$ & N/A & $\begin{array}{c}\mathbf{0 . 8 7 7} \\
(0.015)\end{array}$ & $\begin{array}{c}-\mathbf{0 . 7 7 9} \\
(-1.5)\end{array}$ & N/A & $\begin{array}{c}\mathbf{0 . 5 0 7} \\
(0.015)\end{array}$ & $\begin{array}{l}\mathbf{0 . 1 4 4} \\
(-1.5)\end{array}$ & $\begin{array}{l}-0.02 \\
(1.0)\end{array}$ & $\mathrm{N} / \mathrm{A}$ \\
\hline & Reactive power & N/A & N/A & N/A & N/A & N/A & $\begin{array}{c}-\mathbf{0 . 0 1 9} \\
(-0.6) \\
\end{array}$ & $\begin{array}{c}\mathbf{0 . 2 9 8} \\
(0) \\
\end{array}$ & $\mathrm{N} / \mathrm{A}$ & $\begin{array}{c}-\mathbf{0 . 0 1 9} \\
(-0.6) \\
\end{array}$ & $\begin{array}{c}\mathbf{0 . 0 6 1} \\
(0) \\
\end{array}$ & $\mathrm{N} / \mathrm{A}$ & N/A & N/A \\
\hline & Reactive energy & N/A & N/A & N/A & N/A & N/A & N/A & N/A & $\begin{array}{c}-\mathbf{0 . 2 1 1} \\
(-0.6) \\
\end{array}$ & N/A & N/A & $\begin{array}{l}\mathbf{0 . 0 8 2} \\
(-0.6) \\
\end{array}$ & N/A & N/A \\
\hline \multirow{4}{*}{ 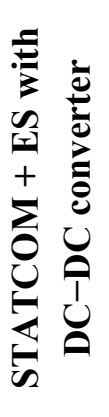 } & Active power & $\begin{array}{c}\mathbf{0 . 2 9 7} \\
(0.101) \\
\end{array}$ & $\begin{array}{c}\mathbf{0 . 4 2 1} \\
(0.101) \\
\end{array}$ & $\mathrm{N} / \mathrm{A}$ & $\begin{array}{c}\mathbf{0 . 0 0 6} \\
(0.00017) \\
\end{array}$ & $\begin{array}{c}\mathbf{0 . 9 0 6} \\
(0.148) \\
\end{array}$ & N/A & $\begin{array}{c}\mathbf{0 . 2 0 1} \\
(0.1) \\
\end{array}$ & N/A & N/A & $\begin{array}{c}\mathbf{0 . 3 7 9} \\
(0.1) \\
\end{array}$ & N/A & N/A & $\begin{array}{r}\mathbf{0 . 9 6 6} \\
(0.9) \\
\end{array}$ \\
\hline & Reactive current & $\begin{array}{c}-\mathbf{0 . 0 2 1} \\
(-1.0) \\
\end{array}$ & $\begin{array}{c}-\mathbf{0 . 3 9 5} \\
(-1.0) \\
\end{array}$ & $\begin{array}{r}3.859 \\
(1.0) \\
\end{array}$ & $\begin{array}{c}\mathbf{1 . 3 7 5} \\
(1.0) \\
\end{array}$ & $\begin{array}{c}\mathbf{0 . 3 5 9} \\
(0.30378) \\
\end{array}$ & N/A & $\begin{array}{r}\mathbf{0 . 6 6 7} \\
(0.015) \\
\end{array}$ & $\begin{array}{c}-1.046 \\
(-1.5) \\
\end{array}$ & N/A & $\begin{array}{c}\mathbf{0 . 4 9 1} \\
(0.015) \\
\end{array}$ & $\begin{array}{r}\mathbf{0 . 6 4} \\
(-1.5) \\
\end{array}$ & $\begin{array}{l}-0.01 \\
(1.0) \\
\end{array}$ & N/A \\
\hline & Reactive power & N/A & N/A & N/A & $\mathrm{N} / \mathrm{A}$ & N/A & $\begin{array}{c}-\mathbf{0 . 0 5 7} \\
(-0.6) \\
\end{array}$ & $\begin{array}{c}\mathbf{0 . 3 0 4} \\
(0) \\
\end{array}$ & N/A & $\begin{array}{c}-\mathbf{0 . 0 3 4} \\
(-0.6) \\
\end{array}$ & $\begin{array}{c}\mathbf{0 . 2 1 7} \\
(0) \\
\end{array}$ & $\mathrm{N} / \mathrm{A}$ & N/A & N/A \\
\hline & Reactive energy & N/A & N/A & N/A & N/A & N/A & N/A & $\mathrm{N} / \mathrm{A}$ & $\begin{array}{c}-\mathbf{0 . 3 0 6} \\
(-0.6)\end{array}$ & N/A & N/A & $\begin{array}{l}\mathbf{0 . 2 2 8} \\
(-0.6)\end{array}$ & N/A & N/A \\
\hline
\end{tabular}


In the German case, the requirements in Zones 1, 2 and 3 require the generator to deliver more reactive current; with the use of a STATCOM alone, it was not possible to deliver the maximum reactive current (note that the maximum reactive current generation in the German's grid code is only by the request of the $\mathrm{SO}$ ). Note that the active power generation during a voltage dip becomes an issue because of the low capability of the STATCOM to inject active power into the grid. This requirement and the reactive current requirement were fulfilled using an SC in the STATCOM's DC link, as found in Table 4. Moreover, it was also possible to deliver as much active power as requested in the German grid code using the STATCOM + ES with the bidirectional DC-DC converter; although the simulations results with the SC in the DC link and the DC-DC converter seem to be quite similar, it was possible to deliver more active power with the addition of the DC-DC converter. However, the UK's grid code still has the same deadband issue; with the $\mathrm{SC}$, the generation of reactive current starts at $5 \mathrm{~ms}$, and the maximum reactive current is reached at $9 \mathrm{~ms}$.

Finally, one of the most important achievements can be seen in Figures 15 and 18, where the SC is placed in the low voltage side of the DC-DC converter (STATCOM + ES + DC/DC); in this case, the STATCOM was able to deliver more active power than in the other approaches.

\section{Conclusions}

The first part of this paper presented the analysis of the LVRT requirements in the grid codes for a set of countries that represent the worldwide trends in wind energy. The more demanding codes appear to be the German and the UK codes, because they demand that the WTG has to withstand a fault down to zero volts in the PCC, and they do not allow any reactive consumption during the voltage dip.

Next, the methods that enable the FSWGs to fulfill the LVRT requirements of the grid codes were analyzed. This type of WTG was selected for two reasons: it has an important presence in the countries where wind energy was first developed, and this type of machine cannot fulfill the LVRT requirements by itself, as seen in Table 3. Therefore, this paper presented a system based on a STATCOM installed at the low-voltage side of an FSWG that enables these types of wind generators to fulfill the LVRT requirements. The simulation results indicate that, by means of the proposed configuration, it is possible to fulfill the LVRT requirements of the Spanish and the Danish grid codes. However, for the German case, due to the active power demands, it is proposed to introduce an energy storage device in the DC link, resulting in the STATCOM + ES configuration. In this paper, the use of supercapacitors was proposed for that purpose. The UK's grid code was not satisfied, due to the lack of a deadband that would allow the power electronics to react in time. Note that this code could be fulfilled with only the use of a STATCOM alone if a minimum deadband is considered.

Finally, the inclusion of a DC-DC converter in the DC link of the STATCOM and the supercapacitor in the low voltage side of the converter is proposed; it was possible to deliver a considerable amount of active power into the grid during the fault and restoration of the voltage. This configuration allows control of the power flow between the SC and the grid, because the bidirectional converter provides the possibility to control the discharge of the SC without interfering with the DC link voltage of the STATCOM. By means of this configuration, deeper discharge levels at the SC side are achievable; therefore, more active power could be delivered to the grid without interfering with the reactive power injection. For example, with the use of the STATCOM + ES, 4\% more active power is generated than 
with the STATCOM alone, and with the STATCOM + ES with the DC-DC converter (Danish simulation, Zone 1), $80 \%$ more active power is generated than with the STATCOM alone. This feature of the STATCOM + ES could be further exploited for inertia emulation, to smooth the active power output of the STATCOM, to maintain the DC link voltage as relatively constant or for frequency response.

A method for calculating the required capacitance of the SC during a voltage dip is also suggested. The influence of the power losses in the ESR and the minimum achievable SOC was taken into account to provide the STATCOM the possibility to deliver the energy required by each of the grid codes investigated.

\section{Acknowledgments}

This work was supported in part by the Ministry of Science and Innovation under contract ENE 2009-13074.

\section{Author Contributions}

Andrés Felipe Obando-Montaño and Camilo Carrillo modelled the complete system and performed simulations. Andrés Felipe Obando-Montaño and Eloy Díaz-Dorado analyzed grid codes and established the simulation scenarios. This work was carried out under the advisement of and with regular feedback from José Cidrás, which reviewed the network models and the results obtained. All author performed results analysis and contributed to writing the paper.

\section{Appendix}

\section{Supercapacitor Parameters}

Power losses in the ESR of the supercapacitor were calculated according to the energy requirement of each country during a voltage dip. For choosing the supercapacitor that fulfills all of the requirements, a database of 36 different supercapacitors from three manufacturers was used; see Table A1 [48-50].

Figure A1. ESR losses in the German case.

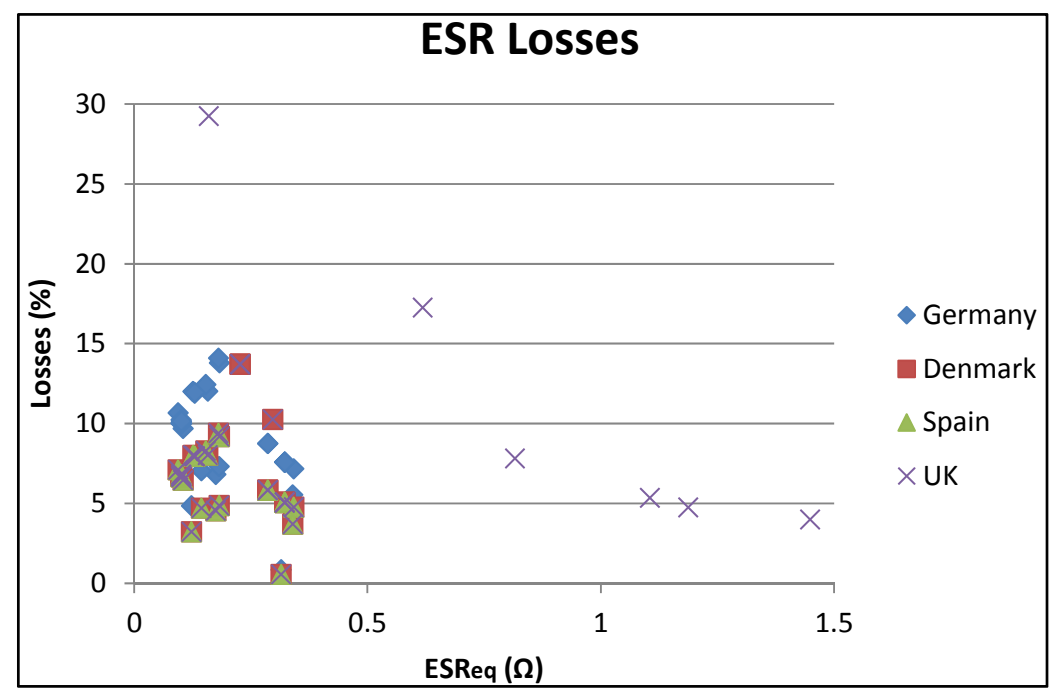


Some assumptions were made in choosing the supercapacitor. The minimum DC voltage was set to be equal to $50 \%$ of its rated value. A mean voltage in the ESR was assumed (taking into account the PSCAD simulations). Then, the power losses were calculated according to the mean values and the duration of the fault. Finally, the results of the losses are depicted in Figure A1, where the mean losses have values of approximately between $5 \%$ and $10 \%$.

Table A1. Supercapacitor database.

\begin{tabular}{|c|c|c|c|c|c|c|c|c|c|c|c|}
\hline Manufacturer & $\mathbf{V}$ & $\mathrm{C}(\mathrm{F})$ & $\operatorname{ESR}(\Omega)$ & Manufacturer & $\mathbf{V}$ & $\mathrm{C}(\mathrm{F})$ & $\operatorname{ESR}(\Omega)$ & Manufacturer & $\mathbf{V}$ & $\mathrm{C}(\mathbf{F})$ & $\operatorname{ESR}(\Omega)$ \\
\hline \multirow{13}{*}{ iouxus } & 16 & 58 & 0.0230 & \multirow{4}{*}{ Maxwell } & 2.7 & 350 & 0.0032 & \multirow{10}{*}{ NESSCAP } & 48 & 111 & 0.0060 \\
\hline & 16 & 500 & 0.0015 & & 2.7 & 310 & 0.0022 & & 48 & 166 & 0.0048 \\
\hline & 81 & 11.7 & 0.0850 & & 2.7 & 650 & 0.0008 & & 64 & 83 & 0.0081 \\
\hline & 48.6 & 165 & 0.0050 & & 75 & 84 & 0.0130 & & 64 & 125 & 0.0064 \\
\hline & 81 & 41.5 & 0.0220 & \multirow{9}{*}{ NESSCAP } & 2.7 & 5000 & 0.0003 & & 86 & 62 & 0.0108 \\
\hline & 81 & 41.5 & 0.0220 & & 16 & 108 & 0.0036 & & 86 & 93 & 0.0084 \\
\hline & 162 & 208 & 0.0450 & & 16 & 200 & 0.0029 & & 125 & 62 & 0.0127 \\
\hline & 54 & 62 & 0.0180 & & 16 & 266 & 0.0025 & & 2.3 & 60 & 0.0230 \\
\hline & 59 & 72 & 0.0200 & & 16 & 333 & 0.0020 & & 2.7 & 50 & 0.0140 \\
\hline & 54 & 62 & 0.0170 & & 16 & 500 & 0.0016 & & 2.3 & 300 & 0.0120 \\
\hline & 108 & 11.4 & 0.0160 & & 48 & 36 & 0.0108 & & & & \\
\hline & 189 & 3 & 0.1030 & & 48 & 66 & 0.0086 & & & & \\
\hline & 216 & 2 & 0.0890 & & 48 & 88 & 0.0073 & & & & \\
\hline
\end{tabular}

\section{Supercapacitor Ratings}

The SC ratings for each of the simulations are presented in Table A2. The data presented are the LVRT energy requirement, the equivalent capacitance and the equivalent resistance calculated with Equation (6).

Table A2. Supercapacitor ratings.

\begin{tabular}{|c|c|c|c|c|c|}
\hline \multirow{2}{*}{ Country } & \multirow{2}{*}{$E_{L V R T}(\mathrm{~kJ})$} & \multicolumn{2}{|c|}{ STATCOM + ES } & \multicolumn{2}{|c|}{ STATCOM + ES DC-DC Converter } \\
\hline & & $C_{S C e q}(\mathbf{F})$ & $\operatorname{ESR}_{e q}(\Omega)$ & $C_{S C e q}(\mathrm{~F})$ & $E S R_{e q}(\Omega)$ \\
\hline Denmark & 363 & 0.418 & 1.630 & 1.71 & 0.2268 \\
\hline Germany & 980.1 & 1.57 & 0.361 & 3.14 & 0.1806 \\
\hline Spain & 594 & 0.6 & 0.304 & 3.14 & 0.1806 \\
\hline UK & 150 & 0.2 & 0.89 & 0.5 & 0.618 \\
\hline
\end{tabular}

\section{Supercapacitor Ratings}

The simulations parameters can be seen from Tables A3-A8. 
Table A3. Technical characteristics of the wind turbine.

\begin{tabular}{ccc}
\hline \multicolumn{3}{c}{ WTG, MADE AE 61 } \\
\hline Parameter & Value & Unit \\
\hline Rated power & 1,320 & $\mathrm{~kW}$ \\
Diameter & 61 & $\mathrm{~m}$ \\
Swept area & $2,922.5$ & $\mathrm{~m}^{2}$ \\
Rated speed & 16 & $\mathrm{~m} / \mathrm{s}$ \\
Number of blades & 3 & - \\
Max hub height & 55 & $\mathrm{~m}$ \\
Gearbox ratio & $1: 80.8$ & - \\
Inertia constant & 5 & $\mathrm{~s}$ \\
Self-damping & 0.01 & - \\
Power limitation & stall & - \\
\hline
\end{tabular}

Table A4. Induction generator parameters.

\begin{tabular}{ccc}
\hline Parameter & Value & Unit \\
\hline Rated power & 1,320 & $\mathrm{~kW}$ \\
Nominal current & 1.273 & $\mathrm{kA}$ \\
RMS phase-voltage & 0.400 & $\mathrm{kV}$ \\
Poles & 4 & - \\
Synchronous speed & 1,500 & $\mathrm{rpm}$ \\
Inertia constant & 0.7 & $\mathrm{~s}$ \\
Self-damping & 0.1 & - \\
\hline
\end{tabular}

Table A5. STATCOM ratings.

\begin{tabular}{ccc}
\hline Parameter & Value & Unit \\
\hline Rated DC voltage $V_{D C r}$ & 2,000 & $\mathrm{~V}$ \\
DC capacitance $C$ & 5,500 & $\mu \mathrm{F}$ \\
inductance $L_{S}$ & 100 & $\mu \mathrm{H}$ \\
Commutation frequency $f_{\text {STATCOM }}$ & 1,950 & $\mathrm{~Hz}$ \\
Rated line voltage & 690 & $\mathrm{~V}$ \\
Nominal current & 1.273 & $\mathrm{kA}$ \\
\hline
\end{tabular}

Table A6. DC link supercapacitor, German case.

\begin{tabular}{ccc}
\hline Parameter & Value & Unit \\
\hline SC Capacitance $C_{S C}$ & 66 & $\mathrm{~F}$ \\
SC equivalent series resistance, $E S R$ & 8.6 & $\mathrm{~m} \Omega$ \\
Rated SC voltage, $V_{S C r}$ & 48 & $\mathrm{~V}$ \\
Rated DC voltage, $V_{D C r}$ & 2,000 & $\mathrm{~V}$ \\
Number of SC modules, $N$ & 42 & modules \\
Equivalent capacitance, $C_{S c e q}$ & 1.57 & $\mathrm{~F}$ \\
Equivalent ESR, $E S R_{e q}$ & 0.36 & $\Omega$ \\
\hline
\end{tabular}


Table A7. DC-DC converter ratings.

\begin{tabular}{ccc}
\hline Parameter & Value & Unit \\
\hline DC-DC converters inductance, $L_{D C D C}$ & 372 & $\mu \mathrm{H}$ \\
Boost and Buck capacitances, $C_{B o o s t}$ and $C_{B u c k}$ & 4,700 & $\mu \mathrm{F}$ \\
Commutation frequency, $f_{D C D C}$ & 20 & $\mathrm{kHz}$ \\
Buck voltage, $V_{S C}$ & 1,000 & $\mathrm{~V}$ \\
Boost voltage, $V_{d c, r e f}$ & 2,000 & $\mathrm{~V}$ \\
\hline
\end{tabular}

Table A8. DC-DC converter supercapacitor, German case.

\begin{tabular}{ccc}
\hline Parameter & Value & Unit \\
\hline SC capacitance, $C_{S C}$ & 266 & $\mathrm{~F}$ \\
SC equivalent series resistance, $E S R$ & 2.5 & $\mathrm{~m} \Omega$ \\
Rated SC voltage, $V_{S C r}$ & 16 & $\mathrm{~V}$ \\
Rated DC voltage, $V_{D C r}$ & 1,000 & $\mathrm{~V}$ \\
Number of SC modules, $N$ & 63 & modules \\
Equivalent capacitance, $C_{S c e q}$ & 4.22 & $\mathrm{~F}$ \\
Equivalent ESR, $E S R_{e q}$ & 0.1557 & $\Omega$ \\
\hline
\end{tabular}

\section{Conflicts of Interest}

The authors declare no conflict of interest.

\section{References}

1. The European Wind Energy Association. Anual Report 2012; European Wind Energy Association: Brussels, Belgium, 2012.

2. Carrillo, Camilo; Cidrás, José; Díaz-Dorado, Eloy; Obando-Montaño, Andrés Felipe. An Approach to Determine the Weibull Parameters for Wind Energy Analysis: The Case of Galicia (Spain). Energies 2014, 7, 2676-2700.

3. TransmissionCode 2007. Network and System Rules of the German Transmission System Operators. Available online: https://www.vde.com/de/fnn/dokumente/documents/transmissioncode\% 202007_engl.pdf (accessed on 10 May 2013).

4. Energinet Regulation TF 3.2.5 Wind Turbines Connected to Grids with Voltages above 100kV. Eltra and Elkraft System. Available online: http://www.energinet.dk/SiteCollectionDocuments/ Engelske\%20dokumenter/El/Grid\%20Code\%203.2.5\%20Wind\%20Turbines\%20connected\%20 above\%20100\%20kV.pdf (accessed on 10 May 2013).

5. National Grid Electricity Transmission Public Limited Company. The grid code, issue 5, Revision 11. Available online: http://www2.nationalgrid.com/UK/Industry-information/Electricity-codes/ Grid-code/The-Grid-code/ (accessed on 9 September. 2014).

6. Operador Nacional do Sistema Elétrico Submódulo 3.6. Requisitos técnicos mínimos para a conexão às instalações de transmissão (in Portuguese). Available online: http://www.ons.com.br/ download/procedimentos/modulos/Modulo_3/Submodulo\%203.6_Rev_1.0.pdf (accessed on 10 May 2013). 
7. Red Eléctrica de España. REE. P.O.12.3. Requisitos de respuesta frente a huecos de tensión de las instalaciones de producción de régimen especial. (in Spanish). Available online: http://www.ree.es/sites/default/files/01_ACTIVIDADES/Documentos/ProcedimientosOperacion/P O_resol_12.3_Respuesta_huecos_eolica.pdf (accessed on 8 May 2013).

8. Li, H.; Chen, Z. Overview of different wind generator systems and their comparisons. IET Renew. Power Gener. 2007, 2, 123-138.

9. Ackermann, T. Wind Power in Power Systems, John Willey \& Sons: Stockholm, Sweden, 2005.

10. Eriksen, P.B.; Ackermann, T.; Abildgaard, H.; Smith, P.; Winter, W.; Rodriguez Garcia, J.M. System operation with high wind penetration. IEEE Power Energy Mag. 2005, 3, 65-74.

11. Dirección Técnica de AEE. Informe sobre la situación actual y la problemática para la adecuación de los parques existentes a los requisitos previstos por el PO 12.3. Versión 3; Asociación Empresarial Eólica: Madrid, Spain, 2009. (in Spanish)

12. Molinas, M.; Suul, J.A.; Undeland, T. Low voltage ride through of wind farms with cage generators: STATCOM versus SVC. IEEE Trans. Power Electron. 2008, 23, 1104-1117.

13. Díaz-Dorado, E.; Carrillo, C.; Cidrás, J. Control algorithm for coordinated reactive power compensation in a wind park. IEEE Trans. Energy Convers. 2008, 23, 1064-1072.

14. Carrillo, C.; Obando Montaño, A.F.; Cidrás, J.; Díaz-Dorado, E. Response of a fixed - speed wind generators under Low Voltage Ride Through requirements. In Proceedings of the 19th Annual seminar on automation, industrial electronics and instrumentation (SAAEI'12), Guimarães, Portugal, 11-13 July 2012.

15. Vas, P. Sensorless Vector and Direct Torque Control; 1st ed., Hammond, P.; Miller, T. J. E.; Kenjo, T., Eds.; Monographs in Electrical and Electronic Engineering: Oxford, UK, 1998.

16. Hingorani, N.G.; Gyugyi, L. Understanding FACTS; 1st ed., IEEE Press: New York, NY, USA, 1999.

17. Adamczyk, A.; Teodorescu, R.; Mukerjee, R. N.; Rodriguez, P. Overview of FACTS Devices for Wind Power Plants Directly Connected to the Transmission Network. In Proceedings of the 2010 IEEE International Symposium on Industrial Electronics, Bari, Italy, 4-7 July 2010; pp. 3742-3748.

18. Arulampalam, A.; Ekanayake, J.B.; Jenkins, N. Application study of a STATCOM with energy storage. IEE Proc. -Gener. Transm. Distrib. 2003, 3, 373-384.

19. Banos, C.; Aten, M.; Catwright, P.; Green, T. Benefits and Control of STATCOM with Energy Storage in Wind Power Generation. In Proceedings of the 8th IEE International Conference on ACDC, London, UK, 28-31 March 2006; pp. 230-235.

20. Zhengping, X.; Babak, P.; Subhashish, B. Improving distribution system performance with integrated STATCOM and Supercapacitor Energy Storage System. In Proceedings of the IEEE Power Electronics Specialists Conference, Rhodes, Greece, 15-19 June 2008; pp. 1390-1395.

21. Li, W.; Joós, G. A Power Electronic Interface for a Battery Supercapacitor Hybrid Energy Storage System for Wind Applications. In Proceedings of the Power Electronics Specialists Conference, Rhodes, Greece, 15-19 June 2008; pp. 1762-1768.

22. Jie, Z.; Buhan, Z.; Chengxiong, M.; Yunling, W. Use of Battery Energy Storage Improve the Power Quality and Wind Farms System to Improve the Power Quality and Stability of Wind Farms. In Proceedings of the Power System Technology PowerCon, Chongqing, China, 22-26 October 2006; pp. 1-6. 
23. Arulampalam, A.; Barnes, M.; Jenkins, N.; Ekanayake, J. B. Power quality and stability improvement of a wind farm using STATCOM supported with hybrid battery energy storage. IEE Proc. Gener. Transm. Distrib. 2006, 153, 701-710.

24. Barton, J.P.; Infield, D.G. Energy Storage and its Use with Intermittent Renewable Energy. IEEE Trans. Energy Convers. 2004, 19, 441-448.

25. Hossain, M. J.; Pota, H. R.; Ramos, R. a. Improved low-voltage-ride-through capability of fixed-speed wind turbines using decentralized control of STATCOM with energy storage system. IET Gener. Transm. Distrib. 2012, 6, 719-730.

26. Anwar, A.; Ali, M.H.; Dougal, R.A. Supercapacitor Energy Storage for Low-Voltage Ride Through in a 13.8 KV AC System. In Proceedings of the IEEE SoutheastCon 2010, Concord, NC, USA, 18-21 March 2010; pp. 189-192.

27. Bottu, M.; Crow, M..; Elmore, A.C. Design of a Conditioner for Smoothing Wind Turbine Output Power. In Proceedings of the North American Power Symposium (NAPS), Arlington, VA, USA, 26-28 September 2010; pp. 1-6.

28. Faranda, R.; Gallina, M.; Son, D.T.; Elettrotecnica, D.; Milano, P. A new simplified model of Double-Layer Capacitors. In Proceedings of the IEEE International Conference on Clean Electrical Power, Capri, Italy, 21-23 May 2007; pp. 706-710.

29. The International Electrotechnical Commission IEC 61000-4-30 Electromagnetic Compatibility (EMC)-Part 4-30: Testing and Measurement Techniques-Power Quality Measurement Methods; International Electrotechnical Commission: Geneva, Switzerland, 2003.

30. Carrillo, C.; Pérez-Sabín, F.; Díaz-Dorado, E.; Cidrás, J. Flicker Mitigation and Voltage Sag Ride through of a Wind Turbine Using an STATCOM. In Proceedings of the Europe's premier wind energy event EWEC'09; Marsella, France, 16-19 March 2009; Volume 09.

31. Asociación Empresarial Eólica Procedure for verification validation and certification of the requirements of the PO 12.3 on the response of wind farms and photovoltaic plants in the event of voltage dips, Version 9. Available online: http://www.aeeolica.org/uploads/documents/1306-pvvcn9-english.pdf (accessed on 8 May 2013).

32. Manitoba HVDC Research Center PSCAD/EMTDC V4.2.0. Users Guide, A Comprehensive Resource for EMTDC, Transient Analysis for PSCAD Power System Simulation. Available online: https://hvdc.ca/uploads/ck/files/reference_material/EMTDC_User_Guide_v4_3_1.pdf (accessed on 14 April. 2013).

33. Carrillo, C.; Feijóo, A.E.; Cidrás, J.; González, J. Power fluctuations in an isolated wind plant. IEEE Trans. Energy Convers. 2004, 19, 217-221.

34. Gamesa Corporation. Made AE-61-1320kW. Available online: http://www.gamesacorp.com/es/ productos-servicios/madeae611320kw.html (accessed on 26 May. 2013).

35. Carrillo, C.; Obando Montaño, A.F.; Cidrás, J.; Díaz-Dorado, E. Review of power curve modelling for wind turbines. Renew. Sustain. Energy Rev. 2013, 21, 572-581.

36. Noroozian, M.; Taylor, C.W. Benefits of SVC and STATCOM for electric utility application. IEEE PES Transm. Distrib. Conf. Expo. 2003, 3, 1143-1150.

37. Gaztañaga, H.; Etxeberria-Otadui, I.; Ocnasu, D.; Seddik, B. Real-time analysis of the transient response improvement of fixed-speed wind farms by using a reduce-scale STATCOM prototype. IEEE Trans. Power Syst. 2007, 22, 658-666. 
38. Ghosh, A.; Ledwich, G. Power Quality Enhancement Using Custom Power Devices; Kluwer Academics: Boston, MA, USA, 2002.

39. Schauder, C.; Gernhardt, M.; Stacey, E.; Lemak, T.; Gyugyi, L.; Cease, T.W.; Edris, A. Development of $\mathrm{a} \pm 100$ MVAR Static Condenser for Voltage Control of Transmission Systems. IEEE Trans. Power Deliv. 1995, 10, 1486-1496.

40. Mohan, N.; Undeland, T.; Robbins, W. Power Electronics: Converters, Applications and Designs; Wiley: New York, NY, USA, 2003.

41. Grainger, J.J.; Stevenson, W.D.J. Power System Analysis; Stephen, E.H., Ed.; McGraw-Hill: Hightstown, NJ, USA, 1994.

42. Kobayashi, K.; Goto, M.; Yokomizu, Y.; Matsumura, T. Power system stability improvement by energy storage type STATCOM. In Proceedings of the 2003 IEEE Bologna Power Tech Conference, Bologna, Italy, 23-26 June 2003; Volume 2, pp. 23-26.

43. Vanitha, V.; Devarajan, N. Transient Stability Improvement of a squirrel cage induction generator in wind farm using STATCOM with Supercapacitor. Wind Eng. 2012, 36, 197-218.

44. Abbey, C.; Joos, G. Supercapacitor Energy Storage for Wind Energy Applications. IEEE Trans. Ind. Appl. 2007, 43, 769-776.

45. Kosek, J.A.; Dweik, B.M.; LaConti, A.B. Technical characteristics of PEM electrochemical capacitor. Handbook of Fuel Cells; Wiley: Hoobojen, NJ, USA, 2003.

46. Camara, M.B.; Gualous, H.; Gustin, F.; Berthon, A. Design and New Control of DC/DC Converters to Share Energy Between Supercapacitors and Batteries in Hybrid Vehicles. IEEE Trans. Veh. Technol. 2008, 57, 2721-2735.

47. Dixon, J.W.; Ortlizar, M. E. Ultracapacitors + DC-DC Converters in Regenerative Braking System. IEEE Aerosp. Electron. Syst. Mag. 2002, 17, 16-21.

48. IOXUS IOXUS modules. Available online: http://www.ioxus.com/modules (accessed on 10 November 2013).

49. Tecate Group Tecate Group Maxwell Technologies Modules Available online: http://www.tecategroup.com/ultracapacitors-supercapacitors/maxwell.php. (accessed on 10 November 2013).

50. NESSCAP NESSCAP ULTRACAPACITORS. Available online: http://www.nesscap.com/ product/module.jsp. (accessed on 10 November 2013)

51. Xie, H.; Ängquist, L.; Nee, H.; Member, S. Design Study of a Converter Interface Interconnecting Energy Storage with the DC Link of a StatCom. IEEE Trans. Power Deliv. 2011, 26, 2676-2686.

52. Esmaili, A.; Nasiri, A. Power smoothing and power ramp control for wind energy using energy storage. In Proceedings of the 2011 IEEE Energy Conversion Congress and Exposition (ECCE); IEEE: Phoenix, AZ, USA, 17-22 September 2011; pp. 922-927.

53. Suryana, R. Frequency Control of Standalone Wind Turbine. In Proceedings of the 2011 IEEE 33rd International Telecommunications Energy Conference (INTELEC), Amsterdam, Netherlands, 9-13 October 2011; pp. 1-8.

54. Samosir, A.; Yatim, A.H.M. Dynamic evolution control of bidirectional DC-DC converter for interfacing ultracapacitor energy storage to Fuel Cell Electric Vehicle system. In Proceedings of the AUPEC '08. Australasian Universities Power Engineering Conference, Sydney, Australia, 14-17 December 2008; pp. 1-6. 
55. Rahim, A.H.M.A.; Nowicki, E.P. Supercapacitor energy storage system for fault ride-through of a DFIG wind generation system. Energy Convers. Manag. 2012, 59, 96-102.

56. Schauder, C.; Mehta, H. Vector analysis and control of advanced static VAR compensators. IEEE Proc. C Gener. Transm. Distrib. 1993, 140, 299-306.

57. Ong, C.-M. Dynamic Simulation of Electric Machinery using Matlab/Simulink; Hall, R., Ed.; Prentice Hall: Upper Saddle River, NJ, USA, 1997.

(C) 2014 by the authors; licensee MDPI, Basel, Switzerland. This article is an open access article distributed under the terms and conditions of the Creative Commons Attribution license (http://creativecommons.org/licenses/by/3.0/). 